\title{
THE WORKS OF MARX AND ENGELS IN ETHNOLOGY COMPARED
}

INTRODUCTION: MARX AND ENGELS IN THEIR GENERAL RELATIONS

The separation of the contributions to the theory and practice of socialism by Karl Marx and Friedrich Engels was not seriously posited during their lifetimes, but only in the following generation. ${ }^{1}$ The separation, as opposed to the contributions of their entire working lives, of the respective quality of thinking in either case, was a matter of which Engels was conscious, for he wrote: "Marx was a genius, we others were at best talents. Without him the theory today would be far from what it is. Therefore it rightly bears his name." 2 The evaluation by Engels of the relation between the two was duly repeated by their biographers. Mehring wrote: "There is no doubt that Marx was philosophically the greater of the two and that his brain was more highly trained."3 Mayer compared the two: "Marx was driven by the harsh goad of genius; Engels lived under the gentler domination of his rich humanity." 4 Ryazanov simply posited that the collaboration of the two and their mutual support proceeded in perfect harmony, with the minor thesis of Engels's supportive role. ${ }^{5}$ Both Mehring and Ryazanov cited Engels's own words of modesty quoted above. Auguste Cornu has written with reference to the beginning of the collaboration: "Engels' study of the origin of communism was more on the economic and social level than on the philosophical and political plane, and portrayed it as a necessary product of the development of capitalist society. This lent definition to Marx's still theoretical

1 Marx died in March 1883, Engels August 1895.

${ }^{2}$ Friedrich Engels, Ludwig Feuerbach und der Ausgang der klassischen deutschen Philosophie (1888), in Marx-Engels, Werke (MEW), Vol. 21, pp. $291 \mathrm{f}$.

3 Franz Mehring, Karl Marx, E. Fitzgerald tr. (1936), p. 123.

4 Gustav Mayer, Friedrich Engels, Gilbert and Helen Highet tr. (1936), p. 104.

5 D. Ryazanov, Karl Marx and Friedrich Engels, J. Kunitz tr. (n.d.), p. 216. 
and abstract conception."' Cornu, who is of the orthodox school, had reference to the articles on political economy in the DeutschFranzösische Jahrbücher (1844) by Engels. While he concedes nothing to the higher intellectual attainments of one over the other, he develops the theme of the power of abstraction of Marx, of concretion of Engels. That there was identity of thought and activity of Marx and Engels is the view which seeks to establish orthodoxy of the socialist doctrines of various parties; the qualitative difference of their brain power, accordingly, implies no difference in the substance of the production in either, whether in the theory or practice of socialism resp. communism.

The theory that bears Marx's name is one that Marx partly in earnest dissociated from himself. Other designations for the theory with which his name is associated were the contributions of Engels: die materialistische Auffassung der Geschichte, ${ }^{2}$ or materialistische Geschichtsauffassung, ${ }^{3}$ die materialistische Anschauung der Geschichte. ${ }^{4}$ The term der historische Materialismus was first set by Engels: "Diese Schrift [Socialism Utopian and Scientific] vertritt das, was wir den

1 Auguste Cornu, The Origins of Marxian Thought (1957), p. 85. Cornu concludes that in The Holy Family, Marx and Engels developed the same fundamental theme, but Marx more deeply (See his Karl Marx et Friedrich Engels, Vol. 3 (1962), p. 204). Marx on the other hand was still utopian and abstract in the composition of the Economic-Philosophical Manuscripts (1844), whereas Engels brought to him the corrective elements from the study of the economic situation in England (Cornu, ib., Vol. 4 (1970), pp. 267f.). Cornu's reading of the works of Marx and Engels of this period provides detail in support of a frequently encountered generality among the biographers of the two, and historians of the socialist movement generally. The interpretation of the Economic-Philosophical Manuscripts is advanced there in the light of the readings of Ludwig Feuerbach at that time. If, however, Marx's work is read in the light of his subsequent writings, a different, more concrete, and practical understanding will be gained. The exclusion of either the contemporaneous or the long-term view is one-sided in regard to the concepts and praxis. The discussion of the Economic-Philosophical Manuscripts is one-sided if it remains external to the work itself: they have become a symbol of Marx the "humanist" as opposed to Marx the "dialectical materialist", "revolutionist", etc., thus becoming a shuttlecock as between parties and interests, and hence are not evaluated as what they are in their form, internal content and relations.

2 MEW, Vol. 13, p. 469 (review by Engels of Marx, Zur Kritik der Politischen Okonomie (1859), in: Das Volk, No 14, August 6, 1859).

${ }^{3}$ MEW, Vol. 21, p. 27 (Foreword to Friedrich Engels, Der Ursprung der Familie, des Privateigentums und des Staats (1884)); Vol. 19, p. 209 (Die Entwicklung des Sozialismus von der Utopie zur Wissenschaft (1880-82)); Vol. 20, p. 25 (Herrn Eugen Dührings Umwälzung der Wissenschaft (1878)).

4 MEW, Vol. 19, p. 210; Vol. 20, p. 248. 
'historischen Materialismus' nennen..."1 These matters have caused some confusion, for we have even been sent for the origin of a term which was Engels's invention to Marx's journalistic articles in Das Volk of August 1859. Marx's position was clearly set forth eight years later when he wrote, in reference to the earthly core of the heavenly forms of religion, that this "is the only materialist, and hence scientific method". ${ }^{2}$ (The insufficiencies of the abstract materialism of the natural sciences, which excludes the historical process, will be discussed below, in Section II.)

Korsch $^{3}$ and Lukács, ${ }^{4}$ who arrived at a related conclusion independently of each other in the early 1920s, explored the difference between Marx and Engels not as to their respective parts in the development of socialism as a program of political action, still less as to the significance of the difference in quality of their intellects, which is in any case a biographical and subjective fact, but in the difference of the theoretical contributions of either man, as a matter of substance. The separation of the two was then discussed as the extension of the dialectic to the sphere outside human history, to nature (by Korsch), which was explicitly attributed to the pursuit of the false example of Hegel by Engels (by Lukács). ${ }^{5}$ There the discussion remained for many years, without development.

Hook wrote: "The exact relation between [Marx and Engels] has yet to be tracked down." The orthodox view, he continued, is that of complete identity of the two; he rejected at the same time the views of the critics Thomas Masaryk, Arturo Labriola and R. Mondolfo, "that there was an essential difference between them". Engels, according to Hook, gave a characteristic emphasis to the doctrine of Marx; Engels brought out the theories of Marx as a "hypothetico-deductive system", a "closed system", a "simplified materialism", to which Marx's "naturalistic activism" is contrasted. ${ }^{6}$ Marx, according to Hook, was a naturalist

1 MEW, Vol. 19, p. 527 (Introduction of 1892 to Die Entwicklung des Sozialismus von der Utopie zur Wissenschaft).

2 Karl Marx, Das Kapital, Vol. 1, 7th ed. (1914), p. 336. Cf. Karl Korsch, Karl Marx (1938), p. 168; id., G. Langkau ed. (1967), p. 145.

3 Karl Korsch, Marxismus und Philosophie (1923), E. Gerlach ed. (1966).

4 Georg Lukács, Geschichte und Klassenbewusstsein (1923), in Werke, Vol. 2 (1968)

${ }^{5}$ Lukács, op. cit., p. 175 note. A review of the problem at the time is given by Korsch in the 1929 edition of his work, and in E. Gerlach's account, introducing the 1966 ed. of it. Lukács, op. cit., p. 32, attributes his separation from the common position with Korsch to the impossibility of fighting fascism outside the (Communist) Party.

- Sidney Hook, Toward the Understanding of Karl Marx (1933), pp. $29 \mathrm{ff}$. 
and humanist; 1 Marx and Engels alike maintained an anti-doctrinary and anti-dogmatic viewpoint. ${ }^{2}$

Schumpeter found Marx's economic interpretation of history "doubtless one of the greatest individual achievements of sociology to this day", his theory serving to unveil economic conditions which shape the religions, ethics, esthetics, political volitions, their rise and fall. Engels in defining his theory of the economic conditions of history as the economic motives was in part wrong, in part "piteously trivial". 3 In his economics Schumpeter held Marx to be "very learned", "a genius and a prophet", his Theories of Surplus Value "a monument of theoretical ardor", and Marx himself a "powerful intellect", etc." Engels, on the other hand, while "eminent", "intellectually and especially as a theorist [...] stood far below Marx. We cannot even be sure that he always got Marx's meaning."5 Thus we have come a long way from the viewpoint of Plekhanov, in which no essential difference was envisaged between Marx and Engels. ${ }^{6}$ Troeltsch ${ }^{7}$ and Von Mises, ${ }^{8}$ who were in the opposite camp from Plekhanov, share the latter's view.

The philosophy of Marx and Engels has been characterized by Hayek as Hegelian positivism. ${ }^{9}$ This term was applied by Licht-

1 S. Hook, From Hegel to Marx (1936), pp. $217 \mathrm{f}$.

2 Ib., pp. 206, 285. See also Hook, Reason, Social Myth and Democracy (1940), Ch. 9.

${ }^{3}$ Joseph Schumpeter, Capitalism, Socialism and Democracy, 3rd ed. (1962), pp. 10-11. Schumpeter, however, was incapable of comprehending Marx's dialectic or relation to Hegel. On Schumpeter and the history of the problem, cf. Roman Rosdolsky, Zur Entstehungsgeschichte des Marxschen "Kapital", Vol. 1, 2nd ed. (1969), pp. 8-9. See also Helmut Reichelt, Zur logischen Struktur des Kapitalbegriffs bei Karl Marx (1970), pp. 13f. E. J. Hobsbawm is of the opinion that Engels oversimplified, thinned out Marx's thought somewhat, having clarity of exposition in view. Cf. his Introduction, p. 18, to Karl Marx, Pre-Capitalist Economic Formations (1964).

4 Ib., p. 21.

Ib., p. 39.

'Cf. G. V. Plekhanov, "Ocherki po istorii materializma", Part 3, in Izbrannye Filosofskie Proizvedeniya, Vol. 2 (1956), pp. 128-194 (Beiträge zur Geschichte des Materialismus (1896), Part 3). Cf. also Plekhanov (N. Bel'tov), K voprosu o razvitii monisticheskogo vzglyada na istoriyu (1895) (The Development of the Monist View of History, A. Rothstein tr., 1947), Ch. 5. Here the relation of Engels and Morgan in relation to Marx's view is discussed.

${ }^{7}$ Ernst Troeltsch, Der Historismus und seine Probleme (1922) (1961), p. 315 : Dioskurenpaar.

${ }^{8}$ L. von Mises, Socialism, 2nd ed. (1953), pp. 302f., 395f. Marx is made the author of the materialist conception of history. See ref. Sartre, p. 228, note 2 below.

- F. A. Hayek, The Counter-Revolution of Science (1955) (1964), pp. $204 \mathrm{f}$. 
heim $^{1}$ and Jordan ${ }^{2}$ to Engels alone. Habermas, in contrast to Jordan who has made Marx into a naturalist, has divided the naturalism-humanism of Marx from the naturalistic cosmology of Engels; Marx's naturalism is opposed by Habermas to the metaphysical materialism of the epigones, Engels and Kautsky, Lenin and Stalin. ${ }^{3}$ The idea of Cornu, that Engels was the more concrete thinker as between the two was put in a variant mode by Cole: Engels was of a more practical bent, directing Marx who was "by temperament a scholar", according to Cole, towards "realism, and away from abstractions masquerading as higher

1 George Lichtheim, The Origins of Socialism (1969), p. 59: "the positivist version of Marxism [...] by Engels and Kautsky". See also Lichtheim, Marxism (1964), p. 238 note: Socialism, Utopian and Scientific and other later writings of Engels "are a veritable compendium of the new positivist world-view". But cf. Herbert Marcuse, Reason and Revolution (1960), Preface; ib., p. 323: "This absolutism of truth completes the philosophical heritage of Marxism and once for all separates dialectical theory from the subsequent forms of positivism and relativism." Plainly an issue is to be resolved here which has not been driven to its end. See T. W. Adorno, Negative Dialektik (1966). The issue of positivity and positivism in application of the dialectic to nature by Engels, to human history by Sartre (see below, p. 228, note 2), or by Jonas Cohn, Theorie der Dialektik, to epistemology, remains to be laid bare. The volume put out by T. W. Adorno et al., Der Positivismusstreit in der deutschen Soziologie (1969), has taken up some of these issues.

${ }^{2} \mathrm{Z}$. A. Jordan, The Origins of Dialectical Materialism (1967), p. 15. Jordan here proposes the following schema: Engels's dialectic materialism is equated to Hegelian positivism, Marx's trend of thought to naturalism. Jordan, whose learning is great, sometimes writes inaccurately. On p. 384 of his work he mentions Croce's view that "historical necessity [... ] allowed Marx to prophesy the coming of the new era". Korsch opposed this. So far so good. But then Jordan writes: "Karl Popper agreed, in substance, with this evaluation, but stated it more incisively." However, the passage cited (Popper, The Open Society and its Enemies, Vol. 2 (1962), pp. 83f.) does not bear out Jordan. It reads: "Socialism [of Marx] was to be developed from its Utopian stage to its scientific stage; it was to be based upon the scientific method of analysing cause and effect, and upon scientific prediction. And since he assumed prediction in the field of society to be the same as historical prophecy, scientific socialism was to be based upon a study of historical causes and effects, and finally upon the prophecy of its own advent." Popper, then, did not agree with Korsch's evaluation but with Croce's, for both impute to Marx a prophetic role, one arming him for this with historical necessity, the other with historical causes and effects. Korsch's position on Marx and Marxism was the opposite of regarding him as a prophet. On the contrary it is Jordan's interpretation of Marx, side by side with those of Croce and Popper, that places Marx in the class of prophets; according to Jordan, Marx's doctrine is not conceived as a natural necessity but a dialectical inevitability; it is the ideology of redemption; Marx's belief is not scientific but eschatological (Jordan, op. cit., p. 385). According to Popper, op. cit., Vol. 2, p. 332, Engels was more dogmatic than Marx.

${ }^{3}$ Jürgen Habermas, Theorie und Praxis (1963) (1967), p. 167. See also ib., p. 202: "die naturalistische Version, die Engels der Ideologienlehre gab". 
values". Engels, in Cole's view, was a "lively, rather than a profound, thinker". Marx's death freed him from being as he had been, "much more Marxist" than Marx.1 According to Sartre, Engels was more simpliste in his thinking than Marx. ${ }^{2}$

Lichtheim has depicted the development of an Engelsian philosophy alone, in which he has based himself on the writing of Engels from 1883 to $1895 .^{3}$ It is these writings, in the opinion of Lichtheim, which formed the basis of the subsequent orthodoxy of Marxism." Jordan's emphasis has been rather close to Hook's, in which the commonalty between the two is stressed, albeit with a characteristic emphasis given to it by Engels. Alfred Schmidt has developed in a systematic way the difference between the cosmological dialectic of Engels and the historical dialectic of Marx. ${ }^{5}$ The naturalist terminology

1 G. D. H. Cole, A History of Socialist Thought, Vol. 2: Marxism and Anarchism (1954), pp. 310f.

${ }^{2}$ J.-P. Sartre, Critique de la Raison Dialectique (1960), p. 690. According to Sartre, however, it was Marx who "constituted dialectical materialism" (ib., p. 214 note).

The relation of man to nature was not explored deeply by Engels; man as part of nature, including his fantastic and mystical representation of himself and nature, is a complex problem whose (modern) sources are found in Descartes, Hobbes, Spinoza, British empiricism, nineteenth century mathematical controversy over unreal and irrational numbers, etc. In the first place, the dialectical relations of abstraction to concretion in their actual and potential moments on the one side, their subjective and objective moments on the other, have not been brought out in recent discussions referring to man and nature. Sartre, op. cit., pp. 669ff., and Jordan, op. cit., pp. $167 \mathrm{ff}$., have confined themselves to indications of Engels's superficialities, confusions, anti-dialectic (in Sartre: Engels is an analytic not a dialectic thinker; this regime is imposed on Engels by his economism). (Lukács and Korsch will be discussed below in this regard; on Schmidt see below, note 5.) In the second, the alienation of man from nature is, besides a problem of morality and right, one of ontology and epistemology. Marx set forth his positions, in view of the complications of these matters, in the $1840 \mathrm{~s}$. They have not often been since developed with fidelity in the lines indicated by him. Cf. Georges Sorel, Réflexions sur la Violence (1908), Ch. 5, who founded his theory of violence, in particular, the distinction between force and violence, on what he understood to be Marx's theory of the natural in man. The human as opposed to the natural is, according to Sorel's grasp of the Marxian conception, equated with "creation by intelligent will". Of the many oppositions of natural and human in Marx, this is perhaps the least appropriate or apt.

${ }^{3}$ George Lichtheim, Marxism (1964), Part 5, Ch. 3, 4.

4 Ib., pp. $234 f$.

5 Alfred Schmidt, Der Begriff der Natur in der Lehre von Marx (1962). Schmidt brings out the non-ontological character of Marx's materialism, which is a point well worth making in reference to Marx's Feuerbach Theses. The difference between Marx and Engels in regard to philosophical materialism is put bySchmidt (p. 12): the question of Marx's concept of nature necessarily is broadened to the 
in respect of Marx has been introduced by Hook, Habermas and Jordan; Avineri has differentiated Marx's historical dialectic from the application of the dialectic to nature by Engels. ${ }^{1}$ An extensive treatment of the relation of Marx to Engels is that of Fleischer. His view is embodied in the section heading "Marx und Engels - Marx oder Engels?": Engels "codified" the Hegelian categorical materials in regard to nature-philosophy; Marx and Engels had the same world-view, but differed in their philosophies; Engels is the lineal ancestor of the Soviet philosophy of dialectical materialism. ${ }^{2}$

\section{II}

\section{MARX AND ENGELS IN THEIR RELATIONS TO THE DIALECTICS OF NATURAL AND HUMAN HISTORY}

Korsch, Lukács, and many who have followed them, have brought out the conception that Marx separated himself from the doctrine of the dialectic of nature of Engels. This is true as to context and general connotation, insofar as the preponderance of Marx's writings concern the economic relations in society, and the dialectic of man's social, economic, political productions and relations. It was Engels alone who developed the philosophical position of the dialectic of nature, and his interpreters have so understood him; with the exception of Plekhanov, and Lenin, who considered the position as shared with Marx. Marx, however, while he had little to say about the dialectic of nature, and did not work out an explicit system, did not separate himself from the philosophical position absolutely. In the Economic-Philosophical Manuscripts of 1844, Marx posited the potential unity of man and nature: "History is an actual part of natural history, nature becoming man. Natural science in this way later will subsume the science of man

question of the relation between the materialist conception of history and philosophical materialism generally, whereas the question of philosophical materialism in reference to Engels does not arise. (The "materialist conception of history", however, is not a concept of Marx, and the manner in which this phrase is to be applied to his work calls for precise definition.) Nature is defined by Schmidt (pp. 19,75) as being, in the system of Marx, the material of human activity. This needs further discussion as to the young Marx, who conceived of the dialectical relation of the actual separation and potential unity of man's relation to nature. See below, p. 230, note 1 . Marx, at the time that he wrote Capital, broadened the systems of human activity in relation to nature. See below, p. 231, note 1, and p. 233, notes 1-4. For an appreciation cp. Jürgen Habermas, Erkenntnis und Interesse (1968), pp. $49 \mathrm{ff}$.

1 Shlomo Avineri, The Social and Political Thought of Karl Marx (1968), p. 202.

2 Helmut Fleischer, Marx und Engels (1970), pp. $174 \mathrm{ff}$. 
under itself, just as the science of man will subsume natural science. It will become one science."1

The separation of man from nature is increasingly deep in the condition of civilization. In this connection Marx wrote: "In allen Formen, worin das Grundeigentum herrscht, die Naturbeziehung noch vorherrschend. In denen, wo das Kapital herrscht, das gesellschaftlich, historisch geschaffne Element."2 Marx's comment in the Introduction to the Grundrisse der Kritik der politischen Okonomie separates social formations in which property in land dominates from those in which capital dominates. In the former, the relation to nature is predominant, in the latter the socially and historically created element. This formulation sets the capitalist period on one side, and the ancient Oriental society, classical antiquity, and medieval feudalism, etc., on the other. The primordial communal existence of mankind is a fortiori to be put in the same category as the Oriental, classical, etc., modes of production, insofar as it shares with them a non- or pre-industrial production in society, and has a minimum amount of formation of capital. On the other hand, the problem of property in land in primitive society is different from that of Oriental, classical feudal or capitalist societies, just as the relations of social class, or their absence, are different. The nature of the peasant community in the ancient or traditional Orient is again different from that of the primitive community. The incomplete grammatical formulation of Marx indicates that here many problems are yet to be resolved; Marx did not prepare this piece of writing for publication.

In the reference to the division of labor in the primitive family and tribe, Marx posited the relation of man, including the primitive peoples, to nature. Natur, naturwïchsig, are but one side of the life of the primitive peoples. Marx wrote: "On the other hand as I remarked earlier, exchange of products arises at the points where different families, tribes, communities, come into contact, for it is not private persons but families, tribes, etc., which stand face to face independently in the beginnings of culture [in den Anfängen der Kultur]." Thus Marx caused nature and culture to stand in opposition even in the life of primitive man. "Different communities [Gemeinwesen]", he continued, "find different means of production and different means of subsistence in their natural environment. Their mode of production, mode of life

1 Karl Marx, Ökonomisch-Philosophische Manuskripte (1844), in Marx-Engels, Historisch-Kritische Gesamtausgabe, I, Vol. 3, pp. 122-123. See L. Kra: er, "Critique dialectique de la nature de la nature humaine", in: L'Homme et la Société, No 10 (1968), pp. 22-23, and Addition 2, at end.

2 Karl Marx, Grundrisse der Kritik der Politischen Ökonomie (1857-1858) (1953), p. 27. 
and products are therefore different." 1 Here there is firm ground for rejection of any notion that Marx separated absolutely primitive from civilized man. All men are cultural, hence the allusion to the beginnings of culture in primitive communities. The life of primitive man is such that the natural environment imposes its regime on the beginnings of culture and differences of modes of production and of life arise out of this. Naturally. Primitive man has not dominated and transformed the natural environment in the degree and way that civilized man has done.

The opening sentence of the Communist Manifesto divides the history from the prehistory of mankind upon the basis of class strugles. ${ }^{2}$ This principle is implicit in the passage quoted from the Introduction to the Grundrisse, but the relation between the two is still problematical and remains to be worked out. The modification introduced by Engels in the 1888 edition of the Manifesto as a footnote to the opening sentence yet left the substance of the separation between natural and cultural-historical man; here Engels wrote: "That is, all veritten history." His note then alludes to the ownership of land in common by Russian peasants, the same practices in their historic past of Teutonic agriculture, and as primitive communism laid bare by Morgan's discovery of the gens. Engels noted: "With the disappearance of these primeval communities society begins to be differentiated into separate and finally antagonistic classes." The objection to this grouping of the phenomena is that the Russian peasants had already formed as a class, and had expressed antagonism to the landowners in many revolts during the centuries prior to Engels's note; Engels did not separate these people and their actions and institutions clearly from the ancient Teutons and the primordial gentile organization.

Aside from the content there is a question of style. The opening sentence of the Communist Manifesto drew attention to the class struggles, and to the historical importance of this phenomenon. Engels's note withdraws the attention from the opening declaration and, by implication, from the entire Manifesto as a manifesto, as a declaration of class war, as an act of the Communist Party toward its end. Engels made the form and content of the phrase into a negotiation about the nature and forms of historiography. The note in question thereby transforms a political act into a scholarly debate; he defended one side of this with a weapon inadequate to its task. Finally,

1 Marx, Kapital, Vol. 1, op. cit,, pp. 336-337.

"Karl Marx and Friedrich Engels, The Communist Manifesto, Ch. 1, incipit:

"The history of all hitherto existing society is the history of class struggles." 
on the question of civilized and primitive man in his relation to nature Engels retired to a previously prepared position, in which man was seen not in his unity but in a duality, a non-dialectical separation, an anti-dialectical position.

Marx moved from this duality, which was still carried forward in his writing of the $1850 \mathrm{~s}$, to a position of the actual unity of mankind, in which primitive and civilized men were separated in their relations to nature and themselves only by their social relations and productive relations in particular, concrete societies and social situations. Already in certain passages of Capital, and more definitively in positions interpolated by him into the excerpts from Morgan and Maine, which will be introduced below, in Section III of this paper, Marx affirmed the unity of human culture and of the historical processes within it.

The formulation by Marx in the first volume of Capital, mentioned above (see p. 225, note 2), appears on the surface to be a separation of the dialectics of man and nature, but not entirely: "The insufficiencies of the abstract natural-science materialism, which excludes the historical process, is to be noted already from the abstract and ideological representations of its spokesmen, as soon as they have departed from their specialty." The materialism of the natural sciences is separate from that of human history by virtue of its abstraction; but this would be also true of the materialism of the historical process: according to Marx, in the study of human history, the materialist and hence scientific method would cease to be such in its abstraction; the evidence for the insufficiencies of the scientific materialism of the spokesmen of natural science lies in their abstract and ideological representations. ${ }^{1}$ There is nothing in this passage that denies the potential unity of the sciences of man and nature, once the abstractions of natural science are made concrete and the abstract and ideological Vorstellungen of its spokesmen are subjected to critique; therefore the well-known formulation in Capital is to be considered in the light of the passage in the Economic-Philosophical Manuscripts, and vice versa. The difference between the two is nevertheless considerable: in the formulation of 1844, the potentiality of nature is that it become human. Marx had industry in view, that part of nature which is comprised within the human sphere, even though in an alienated form. ${ }^{2}$ In Capital, and in the correspondence conducted about the time of its completion, Marx indicated that he had a form of natural science in mind broader than the science of the industrial part of nature

1 Marx, Kapital, loc. cit.

2 Okonomisch-Philosophische Manuskripte, loc. cit. 
which is subsumed within human history: he wrote that according to Hegel's law, merely quantitative changes at a certain point are converted into qualitative differences. ${ }^{1}$ The reference is both to the transformation of the master craftsman of the middle ages into the capitalist, which the guild system tried to prevent by force, and to the molecular theory applied in modern chemistry. The footnote in which this formulation by Marx appears was changed in the third edition of Capital by Engels; nevertheless we note that the entire passage, including the footnote appended to it, develops the law governing the relation of quantitative change and qualitative difference both in chemistry and in the medieval-modern history of Europe. The use of the word "applied" is not to refer to applied chemistry (or industrial, etc., chemistry) but to all chemistry, pure, applied, etc. Marx's letter to Engels of June 22, 1867 makes the same points. ${ }^{2}$ The hand of Engels is to be noted not only in the content of the footnote to the third, or posthumous, edition of Capital but also in the correspondence. Engels also added to the third edition of Capital a further note, made by Marx on the margin of Marx's own copy of the book, referring to quantity-quality in economics. ${ }^{3}$ It follows that this aspect of Marx's conception of the dialectic and of materialism (each of these conceptions formulated by him in their separation from each other) was applied by him both to man and to nature, nature being taken both as separate from man, and as the industrial part comprised with the human technology. This problem is at first separate from but eventually one with the unity of human and natural history. (See above, in reference to the EconomicPhilosophical Manuscripts.)

Marx wrote in the chapter of Capital devoted to the Historical Tendency of Capitalist Accumulation: "But capitalist production begets, with the necessity of a natural process, its own negation. It is the negation of negation." Marx returned to this thought in the letter to Otechestvennye Zapiski dated November 1877 (ca.)..$^{5}$ The process is not a comparison or an analogy, that is, it is not a literary figure. The natural process and the economic process are the same in this regard: it is the negation of the negation. The formulation is to

1 Marx, Kapital, Vol. 1, op. cit., pp. 272-273.

${ }^{2}$ MEW, Vol. 31, p. 306; Marx and Engels, Selected Correspondence, I. Lasker tr. (1965), p. 189.

${ }^{3}$ Marx, Kapital, Vol. 1, op. cit., p. 593 note.

4 Ib., p. 728, also pp. 303-304.

5 MEW, Vol. 19, p. 108; Selected Correspondence, op. cit., p. 312. On chronology cp. Karl Marx, Chronik seines Lebens in Einzeldaten, V. Adoratskij ed. (1934), p. 365 . 
be found in Hegel and in Engels. It is an inaccuracy to put Marx on one side, therefore, and Engels as the applicator of Hegel on the other. At the same time, Marx's statement of his relation to Hegel, to the dialectic, and to the material world is clearly set forth at the end of the preface to the second edition of Capital, January 24, 1873. Here the dialectic is conceived in its historical, human, social reference alone. Moreover, Marx separated the thought of the history of natural technology, the formation of plant and animal organs as instruments of production of plant and animal life (Darwin's interest) from the history of formation of productive organs of man in society. He followed Vico in separating natural history, which we have not made, from human history, which we have made (factum). ${ }^{1}$ The dialectic of man in relation to nature as opposed to the dialectic of nature is developed by Marx in the Theories of Surplus Value, which reveal a close conformity of content and form with his earlier EconomicPhilosophical Manuscripts, Theses on Feuerbach, and The German Ideology. According to the formulations in the Theories of Surplus Value, man is the result of the natural processes, but once posited, he enters into relations as presupposition only as his own product and result. ${ }^{2}$ This is the primary sense in which Marx's theory of man as self-producer is to be understood. (The point has not been well grasped by Hannah Arendt, who has denied that man makes himself, considering that she controverts Marx thereby.) ${ }^{3}$

Marx eschewed such terms as "historical materialism" or the "materialist interpretation of history"; the closest that he came to such capsule phraseology was his reference to "the materialist hence scientific method". This method refers to the concretion of science as opposed to its abstraction, to the concrete demystification of religion, the latter being an abstraction. The materialist basis of religion is opposed to its mystification or heavenly form, hence its abstraction. But this is only part of the scientific method, just as natural history is only one part of the science of nature. Within human history is mathematics, which is man-made, according to Vico, and which therefore should belong to human history. Mathematics has its history, but lies partly within partly without any historical chronology. The relation between the different relations of mathematics to the temporal developments remains to be explored.

Mathematics is of course not the only aspect of science that has a complex relation to history or to temporality. History and temporality,

1 Marx, Kapital, Vol. 1, op. cit., pp. $335 f$.

2 MEW, Vol. 26.3, p. 482, also pp. 289, 414.

${ }^{3}$ Hannah Arendt, The Human Condition (1958); id., On Violence (1969). 
i.e., the study of events in time, the temporal relations of the events, abstract time in relation to concrete time, the study of sequence singular and plural, reversibility and irreversibility, dimensionality, and many other problems besides, are not identical. Non-mathematical aspects of science are historical and also non-historical, as Marx pointed out in the Introduction to the Grundrisse (1857-58). There, in the third section, on the method of political economy, he posited that the historical order of appearance of phenomena is not the same as the order in which they appear in scientific analysis; thus, the order of science and that of history are to be differentiated.

In the development of the scientific or materialist method, The German Ideology occupies a special place. Marx and Engels assigned a great importance to this work, persevering in their efforts to have it published and finally agreeing to the publication of a part (critique of Karl Grün) in the Westphalian Dampfboot, and in an indirectly related piece (against Carl Heinzen) in the Deutsche Brüsseler Zeitung, both in 1847. Marx gave a precise and sympathetic appreciation of the work in the Preface to the Critique of Political Economy of 1859. Failing its original purpose, that of publication, Marx drew from it, with Engels, as the chief aim, self-understanding. This bitter confession was unsatisfactory to Engels, who still persevered in his efforts, discussing its publication with Eduard Bernstein in 1883, after the death of Marx, but in vain. The first part of the work, on Feuerbach, was brought out by D. Ryazanov. ${ }^{1}$ In his editorial introduction, Ryazanov distinguishes between the "materialistische Geschichtsauffassung" and the theory of the "Vorwiegen des wirtschaftlichen Faktors in der Geschichte". This is an important point, but although it was made over forty years ago, has been lost to view, together with its author.

The German Ideology has a number of unclear points, both those of editorial form, and of substance, the latter deriving in part from the given state of the editorial work on the manuscript. Although the work was prepared for publication, the form in which we have it does not reflect exactly the state in which it was left by Marx and Engels, in particular Ch. 1, on Feuerbach. The entire work is joint between them, unlike The Holy Family whose individual parts and sections have been assigned to the authorship of one or the other. The question of author-

1 "Marx und Engels über Feuerbach: Der erste Teil der 'Deutschen Ideologie",', D. Rjazanov ed., in: Marx-Engels Archiv, Vol. 1 (1926), pp. 205-306. The editorial introduction by Ryazanov is the most synoptic history of the manuscript available. See also MEW, Vol. 3, pp. viff. Further circumstances of its publication are given by A. Cornu, Karl Marx et Friedrich Engels, Vol. 4 (1970), pp. 170ff. (See Addition 2, below.) 
ship of The German Ideology is important because some of its formulations touch the question of the degree of commitment of Marx to the dialectics of nature, in particular the first chapter, which is devoted to Feuerbach. (This chapter must, at the same time, be studied in relation to Marx's preface to The German Ideology and to his Theses on Feuerbach.) Ryazanov, in his introduction to the chapter on Feuerbach assigned the first section, entitled Die Ideologie überhaupt, namentlich die deutsche, to Marx. But Marx's characteristic phrasing is evident in later sections of the chapter as well. We will consider tho whole chapter as basically, although not exclusively, the work of Marx.

Two questions in this work are relevant to the discussion of the materialist conception. The first is posed in the subtitle to the chapter Gegensatz von materialistischer und idealistischer Anschaunng. According to Ryazanov, this subtitle was added in pencil at the end of the chapter, in Engels's hand, but the date of this addition is nowhere given. It may have been added when Engels returned to the work in 1888 (see p. 235, note 1), and internal evidence from Engels's own work on Feuerbach points to this conclusion, but this is not sure. It was neither the conception nor the phrase of Marx, and probably was not seen by him. The chapter on Feuerbach, unlike the remaining two chapters of Part I of The German Ideology, alone bears a subtitle. (The chapters of the second part of the work, on the other hand, all bear subtitles.) The formal side of the question, important in itself, is here introduced in support of the notion that it was not Marx who brought into the chapter on Feuerbach the notion of or concern with the opposition between the materialist and idealist conceptions. The abjuring of formalization of thought of this kind is consistent with the general behavior of Marx in this regard.

The second question concerns the terms Natur, naturwiichsig, which appear in the chapter on Feuerbach passim. The English editor of The German Ideology has stated that Marx is inconsistent in the use of these terms, but "inconsistent" is perhaps not the right word. Marx widened the signification of the terms to include human history outside the advanced civilizations, referring to man in a state of nature, precapitalist civilization, and the like, as opposed to man in the modern, capitalist period. Further the use of the term appears to designate that which does not arise by conscious design; thus, in the third section of the chapter on Feuerbach, that devoted to Communism, naturwïchsig is followed by an explanatory phrase: "d.h., nicht einem Gesamtplan frei vereinigter Individuen subordiniert ist". This excludes a conception of social relation of the sort associated with Hobbes or Rousseau. The use of Natur, naturwïchsig, Naturwïchsigkeit by Marx in various places in The German Ideology reflects the distinction made by Hegel 
between the whole man and the divided man, which Marx continued to use in Capital, and the distinction between alienated versus true man, or alienated versus true labor, made by Feuerbach, and which is evident in the Economic-Philosophical Manuscripts of Marx. A study especially devoted to this subject, which would divert the attention from the purpose of this essay, is called for. A system of natural philosophy in The German Ideology was avoided by Marx; matters were left without their full elaboration, as opposed to their inconsistency. This is true of the references to nature in Capital and Theories of Surplus Value as well.

Marx was not a man to be pulled in a direction that he had not established for himself. On the other hand, matters in which Marx chose not to work out a full system were put together by Engels in his own writings. They achieve in their sum an importance which was not given to them by Marx himself, although non-systematic statements are found in his work here and there. A subjective judgment cannot be excluded, but nothing that Engels introduced into his edition of Capital in this connection was not already expressed in Marx's own words and thoughts, save for a correction of the history of chemistry which does not alter the matter. Engels likewise urged Marx to consider the natural sciences in relation to the laws of the dialectic, taking the initiative which Marx then pursued. In fine, the reader is required by the examination of all sides of the texts, and on all possible levels, to put these thoughts into words, to examine the relations of one man to the next and of man to words, and through the relation to man and words and deeds to the theory and praxis a century later. The matter is not as it was originally conceived, and, of its many potentialities, one has been given fuller expression and greater importance thereby than it would have attained but for the intervention of Engels, in whom Marx reposed his trust. (In the next section we will take up a further aspect of the doctrine of nature in Marx's works, with respect to his ethnological conceptions, the relations of primitive and civilized men to social and natural laws.)

Marx did not exclude the natural sciences from the dialectic, and therefore did not differ from Engels on the formal side of the question. As to the substance, the dialectic of nature in Engels's writings is to be judged by itself, and not as a product of Marx or of Marxism. The dialectic of human history was likewise developed by the two in different ways. It is not only a question of emphasis, as Hook has written, although it is, to be sure, that in part. The part he has not mentioned refers to the use made by Engels and others of the corpus of Marx's writings, in which these have been made into a canon of the various orthodoxies. The distinction between Weltanschaunng and philosophy appears to be without a difference. The canon of Engels's writings did 
not first appear in the light after the death of Marx, as Lichtheim, who has touched on part of the matter, has put it; Engels's independent production in this regard long antedated the death of Marx. The canonical in the thought of Engels is external to its content, and is at once the relation of Engels to Marx both before and after Marx's death, and our relation to that relation. (In "our relation" I include those who have made the canon such, those who adhere to it, those who are conscious of it without adherence, those who judge it, etc.)

The difference in their relation to Marx and Engels from that of Korsch or the young Lukács is that both the latter sought not only to receive or record; they were not external to the writings as to doctrines of the faithful (including the faithful or reliable historians), but regarded those writings as their matter to be worked. They were faithful at the same time in the sense that they reported the writings or activities accurately, as the reliable historians. There has been a loss of commitment, of intensivity of engagement to the terms and formulations of Marx, and a loss of creativity in the praxis relative to those spheres since the time that Korsch and Lukács were politically active and engaged in writing. (Both were leaders in short-lived revolutionary regimes of the period that followed immediately after the Russian Revolution and the First World War.) Aside from this change of relationship to and with the dialectic there has occurred a change in the external relation to political activity, which was conceived by the later Lukács to be impotent outside the Communist Party. But the question is: which Communist Party, and when? The Communist Party is a party of a given country, and therefore the nation and nationality enters into his consideration. The party in that given country has its history of power and lack thereof. The country may change its shape and size. Lukács hypostasized the Party.

One side-effect of Engels's modesty is that a certain snobbism has entered into the discussion of Marx and Engels; the latter has been derogated save in the eyes of the loyalists, his biographers, and others who have introduced his works, as J. B. S. Haldane. The misprision of Engels has developed lately, and in part among those who are external to the ideas of both Marx and Engels.

\section{III}

\section{THE WORKS OF MARX AND ENGELS IN ETHNOLOGY}

There is no better known work by Friedrich Engels than The Origin of the Family, Private Property and the State. Its genesis is closely related to the work of Marx upon the identical source material: Morgan's 
Ancient Society. ${ }^{1}$ The history of the manuscript of Marx comprising the excerpts and notes made upon Morgan's work, Engels's access to Marx's materials and to Morgan's book and the formal side of the relation of Engels's work on this subject to that of Morgan and of Marx is set forth in the Introduction to The Ethnological Notebooks of Karl Marx. ${ }^{2}$ Relative to the state of ethnological studies of the 1880 s, the work of Marx and Engels can be compared.

Marx was a part of the philosophical anthropology of the 1840s: his dissertation, studies, and activity in the Hegel clubs, his publications, his correspondence with Arnold Ruge and others are evidence of this. ${ }^{3}$

1 1st ed., 1884; 4th ed., 1891-1892. Engels debt to Marx: Prefaces to 1st, 4th ed. and passim. Lewis Henry Morgan, Ancient Society, or Researches in the Lines of Human Progress from Savagery, through Barbarism to Civilization (New York and London, 1877).

2 The Ethnological Notebooks of Karl Marx (Studies of Morgan, Phear, Maine, Lubbock), transcribed and edited, with an Introduction by Lawrence Krader (Assen, 1972). Further bibliographic precisions regarding the following discussion will be found therein. - This work contains the transcription of excerpts and notes made by Marx from the following books: Lewis Henry Morgan, Ancient Society (1877); John Budd Phear, The Aryan Village in India and Ceylon (1880); Henry Sumner Maine, Lectures on the Early History of Institutions (1875); John Lubbock (Lord Avebury), The Origin of Civilisation (1870). The excerpts and notes from the first three works are gathered in Notebook B 146, the fourth in Notebook B 150, of the Internationaal Institunt voor Sociale Geschiedenis. The first three sets of excerpts were made by Marx during the winter of 1880 and the first half of 1881, the fourth late in 1882, some four months before the death of Marx. Beside the excerpts from the works listed, Notebook B 146 also contains excerpts by Marx from works by J. W. B. Money on Java, Rudolph Sohm on ancient and medieval law, and E. Hospitalier on electricity. The Lubbock excerpts and notes are more restricted in form and content than the early notes but reveal, nevertheless, a remarkable state of mental activity of Marx even at the last stage of his life. D. Ryazanov, "Novye Dannye o Literaturnom Nasledstve K. Marksa i F. Engel'sa", in: Vestnik Sotsialisticheskoy Akademii, No 6,1923 , pp. 351-376, has incorrectly appreciated the chronology of these sets of excerpts and notes in the last months and years of Marx's life, relative to the energy and acumen with which Marx worked upon them (see also the German translation of his lecture before the Socialist Academy: "Neueste Mitteilungen über den literarischen Nachlass von Karl Marx und Friedrich Engels", in: Archiv für die Geschichte des Sozialismus und der Arbeiterbewegung, Vol. 11, 1925). This in no way is to diminish the services of Ryazanov in editing and publishing the writings of Marx, including those unpublished at the time of his death. Ryazanov in this lecture first called attention to the excerpts by Marx from Maine and Lubbock, in addition to the excerpts from Morgan known through Engels. - A detailed discussion of the contents and chronology of the Notebooks B 146 and B 150 is given in The Ethnological Notebooks, op. cit., pp. 86ff. 3 The doctoral dissertation is published in MEW, Ergänzungsband 1, pp. 257373: Differenz der demokritischen und epikureischen Naturphilosophie. On the Hegel clubs see the letter of Jenny von Westphalen, August 10, 1841, MEW, Ergänzungsband 1, p. 641. Publications: "Das philosophische Manifest der 
Marx, moreover, wrote far more on the subject of philosophical anthropology, partly as polemic against Hegel, Feuerbach, Proudhon and others, only some of which was published during his lifetime. But the entire corpus, published and unpublished, had an influence on subsequent formulations which can be traced in his writings, such as have come down to us. The recent reeditions of Marx's Theories of Surplus Value by the editorial staffs of the Sochineniya, Moscow, and of the Werke, Berlin, make this clear. ${ }^{1}$

A controversy of late has arisen concerning the continuity or discontinuity of Marx's life and doctrines. In particular, some, as Cornu, maintain that the work upon the economic matters of 1845-46 marks the break-point, for this was the time of the "formation of historical materialism", ${ }^{2}$ or alternatively, its elaboration by Marx and Engels. ${ }^{3}$ The editors of the Werke have regarded the writings of the two as having equally created the presuppositions of dialectical and historical materialism in the period prior to and its systematic elaboration during 1845-46; at this time they founded scientific communism. ${ }^{4}$ The same thought is put in a definitive way by Althusser: "Beginning in 1845 Marx breaks radically with every theory which bases history and politics on an essence of man."5 This has the air of an authoritative statement.

historischen Rechtsschule", in: Rheinische Zeitung, No 221, August 9, 1842 (MEW, Vol. 1, pp. 78-85); "Zur Judenfrage", in: Deutsch-französische Jahrbücher, 1844 (MEW, Vol. 1, pp. 347-377); "Zur Kritik der Hegelschen Rechtsphilosophie, Einleitung”, ib. (MEW, Vol. 1, pp. 378-391). The correspondence with Ruge was published in the same Jahrbuicher (MEW, Vol. 1, pp. 337-346), which Arnold Ruge and Marx edited jointly. Die Heilige Familie (1845) was brought out jointly with Friedrich Engels (MEW, Vol. 2, pp. 3-223). While Engels was the first author listed on the title page, Marx wrote most of the work.

1 The corpus, aside from the volumes mentioned, includes as yet unpublished materials in the IISG, a part of which is now being prepared for publication by H. P. Harstick.

${ }^{2}$ Auguste Cornu, Karl Marx et Friedrich Engels, Vol. 4: La formation du matérialisme historique.

3 Ib., pp. $287 \mathrm{ff}$.

4 MEW, Ergänzungsband 1, p. v.

${ }^{5}$ Louis Althusser, Pour Marx (1966), p. 233. His judgment is onesided. Korsch called attention to Marx's Preface to the Critique of 1859, where Marx indicated that "the first work undertaken for the solution of the doubts that disturbed me was a critical revision of Hegel's Philosophy of Right". This latter work was written in 1843 (MEW, Vol. 1, pp. 203-333), and the Introduction to it published in 1844. His studies had as their outcome that legal relations and forms of the state are rooted in the material relations of life (MEW, Vol. 13, p. 8). Cf. Karl Korsch, Karl Marx (1938), p. 20. According to Marx the materialist factor, or the material relations, were already set forth by him in 1843-44, thus antedating the time limit of $1845-46$ proposed by Cornu, Althusser, etc. The theory setting forth 
We will start from the premiss of both continuity and discontinuity in Marx's work. The development of empirical anthropology, in which we will include ethnology, prehistory, human biology and related disciplines, proceeded during Marx's lifetime. Many of his formulations of the 1840s, which were given in the mode of philosophical anthropology of that time, may be traced in his later writings, including those contained in his ethnological notebooks. ${ }^{1}$

Marx's notes from Morgan fill 98 pages of the Notebook B 146, those from Phear 26, those from Maine 38; the notes from Lubbock fill eight pages of Notebook B 150. The Maine excerpts and notes are distinguished from the others by virtue of the great amount of comment and polemic introduced by Marx in the course of his excerptings. Marx's handwriting was small, with many abbreviations, contractions, and partly common, partly idiosyncratic word shortenings. His coverage of Morgan omits little of significance; he added a number of comments of his own here and there. Engels came upon the notebook at some time late in 1883 . He cannot have familiarized himself with its content as of November 7,1883 , when he prepared the third edition of Capital Vol. 1 for the press. Engels's note to the third edition ${ }^{2}$ mentions the tribe (Stamm), whereas after his conception in The Origin of the Family he would perhaps have written gens in the context given, as he did in his note to the 1888 edition of the Communist Manifesto. He began to search for a copy of Morgan's book at the beginning of January 1884. Unable to find one, he prepared a synopsis of his own, based on Marx's notes from Morgan, from which he read to Eduard Bernstein during the stay of the latter in London which was from the end of February to the beginning of March, $1884 .^{3}$ He found a copy of Morgan in late March 1884, and, armed with Morgan's book, Marx's notes, his own synopsis, plus a background of wide erudition, he completed his small book in the following two months. Engels made no mention in his correspondence at that time of the works by Phear or Maine also contained in Notebook B 146; he mentioned the book by Money, in a letter to Karl Kautsky ${ }^{4}$ and again

that the root of law, right, the state lies in the material relations of life is incompatible with a theory of essences, and is positively related to the subsequent formulations of Marx regarding the ensemble of social relations (against Feuerbach), the scientific or materialist method, etc. Marx had already broken with the philosophy of essence at that earlier time. To be radical means to go to the root of things; Marx had already gone to the root in 1843.

1 See above, p. 239, note 2 .

2 Kapital, Vol. 1, op. cit., p. 316.

3 For the chronology of the composition of Engels's Origin of the Family see The Ethnological Notebooks, op. cit., pp. 388f.

$4 \mathrm{MEW}$, Vol. 36, p. 109. The letter is dated February 16, 1884. 
in a letter to Paul Lafargue; in this place Maine is mentioned by name, but in reference to no work. ${ }^{1}$ Other works in the field of ethnology that Marx excerpted include: Sir John Lubbock, The Origin of Civilisation (1870), which he worked on late in $1882 .^{2}$ Further, Marx excerpted a work by the Russian sociologist M. M. Kovalevsky at length, and inserted comments (these will be discussed below, Section IV).

Marx came to his study of empirical anthropology with the background of his work in philosophical anthropology. At that time he had already read Charles de Brosses, Chr. Meiners and others who had dealt with primitive peoples. Soon after his establishment in London, he took up the study of ethnology again. In 1851 he excerpted a work by W. C. Taylor, The Natural History of Society in the Barbarous and Civilized State (1840). From that time he worked occasionally on books in ethnology until the late 1870 s and early 1880s, when he worked intensively in that field. On occasion he got his friend to excerpt from the literature for him, Engels having gone through passages of H. H. Bancroft, The Native Races of the Pacific States (1874-76), at the request of Marx. ${ }^{3}$

The work of Morgan was called to his attention by Kovalevsky, his "scientific friend". Morgan's work was based in part on his own researches among the Iroquois, and those of his friends and correspondents in Oceania; in part they are based on Morgan's researches in to the ancient Greeks and Romans, and to a lesser degree the Hebrews. Marx had little to add to Morgan on the ethnology of North America or

1 Ib., p. 194. The letter is dated August 11, 1884. Henry S. Maine, Ancient Law (1861), is referred to by implication by Engels, The Origin of the Family, Private Property and the State (1942), p. 70 (translation of Engels, Ursprung, 4th ed.; it will be referred to hereafter as Engels, Origin); MEW, Vol. 21, p. 80. Here Engels refers to Maine's theory of the social progress from status to contract. It is propounded in Maine's work (Everyman's Library, p. 100): "If then we employ Status [...] to signify these personal conditions [i.e. the powers and privileges anciently residing in the family $]$ only, $[\ldots]$ we may say that the movement of the progressive societies has been a movement from Status to Contract." Engels's point, loc. cit., is that this idea had already been expressed in the Communist Manifesto. Marx, however, simply records the theory of Maine in a way that implies his accord, without a claim to right of priority, in his excerpts from Maine, Early Institutions (The Ethnological Notebooks). Maine's restriction of the derivation of status from powers and privileges in the family is here contested as being too narrow. It excludes the powers of the person that lie outside the family in classical antiquity and also outside the restricted field of privileges.

2 See The Ethnological Notebooks, pp. 89, 360, 395f. Also Marx, Chronik, op. cit., p. 374.

${ }^{3}$ See The Ethnological Notebooks, pp. 89f. Marx had already come into contact with the work of Bancroft in conjunction with his critical notes from Kovalevsky, op. cit., IISG, Notebook B 140, pp. 19, 20, 22, etc. Kovalevsky relied heavily on Bancroft in regard to Indians of North America. 
Oceania, but added much data of his own in the ethnology of the ancient and medieval times. Engels added matter and argument of his own, aside from those of Morgan or Marx, in these fields.

Engels wrote in the Preface to The Origin of the Family that it was "in a sense the execution of a bequest", and that Marx had intended to "present the results of Morgan's researches in connection with the findings of his - I may say, within certain limits, our - materialist historical investigation". Engels mentions the critical comments of Marx; nevertheless, his own work could be but a "modest substitute" for that of Marx. ${ }^{1}$

Engels commenced: "According to the materialist interpretation, the determining factor in history in the final instance is: the production and reproduction of immediate life. This is itself again of a double kind. On the one hand the creation [Erzeugung] of the means of existence, of objects of nourishment, clothing, housing and instruments necessary thereto; on the other hand, the creation [Erzeugung] of men themselves, the procreation [Fortpflanzung] of the species. ${ }^{2}$ This phrase by Engels has been criticized by Heinrich Cunow, Eduard Bernstein, the editors of the works of Marx and Engels in the Soviet Union, and the editors of the same in the German Democratic Republic. ${ }^{3}$ Production and reproduction in society are to be distinguished from processes bearing the same names in biology.

Mänchen-Helfen has traced the conception underlying Engels's failure to distinguish a biological from a social and economic one

1 Engels, Origin, Preface.

2 Loc. cit.

3 Heinrich Cunow, "Die Ökonomischen Grundlagen der Mutterherrschaft", in: Die Neue Zeit, Vol. 16 (1897-98), Part 1, pp. 107-108; id., Die Marxsche Geschichts-, Gesellschafts- und Staatstheorie, Vol. 2 (1921), pp. 140ff,; Eduard Bernstein, Introd. to Italian translation of Engels, Ursprung, in: Socialistische Monatshefte, Vol. 4 (1900); Marx-Engels, Izbrannye Proizvedeniya, Vol. 2 (Moscow, 1955), p. 161; Marx-Engels, Ausgewählte Schriften, Vol. 2 (Berlin, 1955), pp. 159f. Cunow's work, as can be seen, is of more than historical importance. However, Otto Mänchen-Helfen (see next note) criticized Cunow for failing to keep up with the burgeoning field of ethnology. But Cunow's mastery of the existing literature was also occasionally inexact. Cunow, Zur Urgeschichte der Ehe und Familie [Ergänzungshefte zur Neuen Zeit, No 14] (1912), pp. 51f., accused Morgan of imposing the notion of civilized men (Kulturmenschen) upon primitive peoples. "Morgan gave the word father the same meaning as procreator." (p. 52) But that is not the usage encountered among civilized men: Engels had just shown that the Code Napoléon, Art. 312, had done exactly the reverse: "L'enfant conçu pendant le mariage a pour père le mari." (Engels, Origin, Ch. 2; MEW, Vol. 21, p. 70) Cunow would then have had to show that Morgan departed from (at least one) civilized usage in failing to distinguish between social and biological parentage. (This is nonsense, to comprise all of civilized usage in one formula.) 
back to The German Ideology. ${ }^{1}$ If this is so then the latter work, or the relevant section of it, must fall outside the area of the economic factor in history. To be sure, Engels sought to differentiate between primitive and advanced societies; in the former the economic gives place to the factor of kinship relations. ${ }^{2}$ The evidence that MänchenHelfen has pointed to in The German Ideology, however, is not unambiguous. Marx there wrote: "Die Weise, in der die Menschen ihre Lebensmittel produzieren, hängt zunächst von der Beschaffenheit der vorgefundenen und $\mathrm{zu}$ reproduzierenden Lebensmittel selbst $\mathrm{ab}$. Diese Weise der Produktion ist nicht bloss nach der Seite hin zu betrachten, dass sie die Reproduktion der physischen Existenz der Individuen ist." 3 "The manner in which men produce their means of subsistence" is "the mode of production" (in the society and the economy of the society), "it is not only to be considered from the aspect that it is the reproduction of the physical existence of the individuals." The reproduction of the physical existence of the individuals is not the same as the reproduction of the physical existence of the sexual couple or of the species. Reproduction is a word that may refer either to a sexual or a socio-economic process, as Cunow and others pointed out. It is not clear that Marx had biological as well as economic reproduction here in mind.

Mänchen-Helfen commented that Marx and Engels had already incorporated the reference to the biological process within the materialist conception because they had not taken the concept of productive force as purely economic, afterwards this indeterminate idea of productive force was abandoned, to be taken up by Engels again, but not Marx, because the former had conceived of a "pre-economic" epoch. Cunow had shown that this notion is wrong, and had proven the unity of the materialist conception of history against Engels. ${ }^{4}$

1 Otto Mänchen-Helfen, "Heinrich Cunow und die Ethnologie", in: Die Gesellschaft, Vol. 9 (1932), Part 1, p. 447.

2 Letter to Marx, December 8, 1882, MEW, Vol. 35, p. 125. Engels wrote: "The similarity between Tacitus's Germans and the tribes of the Northwest Coast is in fact all the more surprising, as the mode of production is so fundamentally different - here fishers and hunters, there wandering animal breeding passing over into agriculture. This proves exactly how at this stage the kind of production is less decisive than the degree of dissolution of the old consanguineal bonds and the old mutual community of the sexes in the tribe."

${ }^{3}$ MEW, Vol. 3, p. 21.

4 Mänchen-Helfen, op. cit., pp. 447f; here, while praising Cunow, he has gone too far, for he has written: "The production of men, the act of procreation and birth, is the same in all societies. There is history only because there are variable factors. The production of people is a constant factor." (As though there were no natural history! We have to deal with the interaction of two kinds of history, 
Engels had taken up one side of the possibilities implicit in the formulation of The German Ideology.

If it is biological reproduction that is referred to, then this part of the work must be excised from the canon of Engels's historical materialism, the canon of the predominance of the economic factor in the interpretation of history, from that of Plekhanov's dialectical materialism, etc. ${ }^{1}$

\section{Marx on Laws of Nature, Primitive Society and Civilized Society}

Marx took up the matters of the economic and social factors in the life of early man in a number of places in his notes on Morgan; his treat-

and not remove man from nature or nature from history. But this is a minor point compared to the services of Mänchen-Helfen.)

${ }^{1}$ Cornu has included The German Ideology within the canon of historical materialism, the editors of MEW have done likewise. But Cornu has written: "Les premiers rapports sociaux, engendrés à la fois par la production et par la procréation ...", op. cit., Vol. 4, p. 178, in reference to The German Ideology. Cf. MEW, Vol. 3, Vorwort, pp. viiff. This is a confusion that introduces biological into social matters. Erhard Lucas, "Die Rezeption Lewis H. Morgans durch Marx und Engels", in: Saeculum, Vol. 15 (1964), pp. 153-176, and "Marx' Studien", ib., pp. 327-343, made a learned survey, but failed to distinguish between the "economic factor in history" and historical materialism as such. Engels had included (Origin, Preface) the biological factor within his idea at that time of historical materialism. Aside from the general theoretical distinction between the concepts of the "economic factor in history" and "historical materialism", it is particularly important to do so in this context. Lucas concludes that the separation of the economic factor from primitive society by Engels had [as one] consequence that Morgan is declared to be a historical materialist (ib., pp. 171f.). But the attribution, "historical materialist", to Morgan by Engels is not the consequence of the separation of human history into economic and pre-economic stages. One could consider Morgan to be a historical materialist not on the basis of his having founded an interpretation of primitive society on the basis of kinship but on that of property. Engels cited Morgan in regard to the latter interpretation (see the end of The Origin of the Family), as well as the former. Finally, Engels modified his welcome of Morgan into the ranks of the historical materialists by asserting that Morgan's economic treatments were "durchaus ungenügend" (Origin, Preface). This plainly means that the economic factor, according to Engels, is indeed to be found in ancient society, including primitive. Engels made increase in wealth to be the decisive factor in the overthrow in ancient society of mother-right and substitution of father-right (Origin, pp. 50f.; MEW, Vol. 21, pp. 60f.). This is connected with the period of decline of gentile society; but prior to that, while gentile society was still flourishing, an economic factor brought about a change in the form of the family, leading to the introduction of father-right and slavery. This factor, according to Engels, was the acquisition of domesticated livestock as property (ib., pp. 47ff.; MEW, Vol. 21 , pp. 58ff.). Engels had not worked out an internally consistent system. On the relation between the materialist conception of history and the economic factor see also George Plekhanov, The Materialist Conception of History (various eds); 
ment of caste ${ }^{1}$ is entirely as a social phenomenon, subject to social laws, whereas in the chapter of Capital which is devoted to the Division of Labor and Manufacture he wrote: "Castes and guilds arise from the action of the same natural law that regulates the separation of plants and animals into species and sub-species, save that at a certain stage of development the heredity of the castes or the exclusivity of the guilds are decreed as social law."2 Marx here differentiated between stages of development of society; on the one side, the laws governing heredity of castes etc. are the same as natural laws; they are, on the other side of the development, subject to human decree. The ambiguity in this formulation is that according to one interpretation, the caste practices of ancient society are conceived entirely as a natural phenomenon; according to this interpretation, a wholly different law, subject to social decree, enters at a different stage of development of human society. According to a second interpretation, the hereditary factors in the ancient laws are natural, as they are in plants and animals; the fact of their being "decreed" (dekretiert) by human society as social law does not alter the natural matter of heredity in the later stage of development, nor suppress the social matter of heredity in the earlier. The ambiguity is cleared up, and the second interpretation alone is posited, in the passage devoted to caste in Marx's excerpts from Morgan. Engels in The Origin of the Family opted for the position set forth in the first alternative. This is not a position that emerges from, or is consistent with, a wholly social conception of man, as it is propounded in Marx's Economic-Philosophical Manuscripts of 1844 and his Theses on Feuerbach. The further statements of this latter conception are to be found in Marx's writings of the late 1850s: Grundrisse and in the Preface to the Critique of 1859. They were further developed in the Theories of Surplus Value, particularly in the third published volume. Marx continually sharpened his formulation of this position in Capital, adding new materials and insights. From the excerpts and notes made by Marx from Lewis Morgan's Ancient Society and Henry Maine's Early History of Institutions it is clear that Marx considered the economic influences in social life to be the primary factor in the early as well as the civilized life of man. The distinction which Engels drew between the economic factor in the primitive and civilized life

G. V. Plekhanov, Izbrannye Filosofskie Proizvedeniya, Vol. 2, pp. 236-266: "O materialisticheskom ponimanii istorii", pp. 267-299: "Ob "ekonomicheskom faktore"”.

1 The Ethnological Notebooks, p. 183.

${ }^{2}$ Marx, Kapital, Vol. 1, op. cit., p. 304. See above, discussion of The German Ideology. 
of man did not correspond to Marx's own conclusions which he expressed in his comments on Morgan and in his opposition to Maine. Marx noted of the Kutchin of the Yukon River region of Canada that they had "three grades or classes of society", which were exogamic units. Marx commented on this: " $u[n d]$ in d[er] Art, nam[en]tlich wie zum Gensprinzip Eroberung hinzukömmt, können nach $\mathrm{u}[$ nd] nach $\mathrm{d}[\mathrm{ie}]$ gentes zur Kastenbildung Anlass geben?" He then added "that as soon as difference of rank between consanguinei of the gentes arises this enters into conflict with the gentile principle and the gens can petrify in its opposite, caste." Here caste is not successive to the gens but synchronous in its opposition; it is regarded as part of the civilized organization of society. Thus one more dividing line between primitive and civilized man was removed by Marx.

\section{Evolution of Society through Stages and Sub-Stages, 1}

The evolution of human society was posited by Aristotle in proceeding from barbarism to political life. The first form of the social life of man is the family, but the village appears to be the prior to the state, which is the combination of villages in large enough number to be nearly or quite self-sufficing. ${ }^{2}$ Aristotle's term for the state is the polis, a form of social life which the Greeks enjoyed, but which many other peoples of that time did not. He defined man by his nature as a zôn politikón. ${ }^{3}$

1 The Ethnological Notebooks, p. 183. In the excerpts from Maine's Early History, Marx made the comment: "Better weaponry is an element resting directly on progress in the means of production (these conjoin directly, e.g., in hunting and fishing with means of destruction, means of war)." (ib., p. 330) The advances in military technology of hunting and fishing peoples is directly related by Marx to the economic factor in their history, in opposition to Engels's suggestion that the economic factor be reserved to civilized peoples. The dialectical opposition in the Morgan excerpt is without temporal movement, that is, in a state of tension against temporal movement, of stored-up temporal movement, ending in the petrification of the gens-caste relation. The dialectical opposition in the Maine excerpts has a temporal movement implicit within itself, which is the progress in the means of production in hunting and fishing (technology); upon this basis the progress in military technology rests. Cf. Marx, Grundrisse, op. cit., p. 76.

${ }^{2}$ Aristotle, Politics, $1252 \mathrm{~b}$. The village appears to be earlier in time than the state, but it is not clear whether the family is logically or chronologically prior to the village according to Aristotle.

${ }^{3}$ Ib., 1253a. Elsewhere I have suggested that Aristotle, in this passage as well as in related parts of the Nicomachaean Ethics, applied the term polis in two senses: as the actual state of all men, and as the actual state of some, the potential state of others. See Lawrence Krader, "The Anthropology of Thomas Hobbes: Violence, a Primitive Human Condition", in: International Society for the History of Ideas, Third International Conference (Philadelphia, 1972). 
But that nature, physis, was not actually present in every human society, for he mentions some who do not live in the polis. Therefore we conclude that the polis is a condition of human life that is the actual nature of some men, the potential nature of others. Some of Aristotle's commentators, such as St Thomas, did not make the distinction between actual and potential in this regard. Hegel drew upon Aristotle's schema; in the Foreword to the second edition of his Logic, Hegel quoted Aristotle's opinion that only after the necessities of life had been assured did the Egyptians turn to philosophy. ${ }^{1}$ Aristotle then adds: "The mathematical sciences were early developed in Egypt because the priestly class was early in the position to have leisure."

The idea of development from lower to higher over time was set forth by Hegel and was applied by him to human history and society. Ritchie had drawn attention to Hegel's concept of Entwickelung as a thought process. ${ }^{3}$ Wallace pointed out that Hegel was not a biological evolutionist; but he was, in the sense given above, a social evolutionist.* How Hegel's system in general, aside from the particularities here cited, is conducive to an evolutionism of the nineteenth century kind has been shown by Fischer, and after him, Cassirer. ${ }^{5}$ The dialectical relations of structural constancy and change was posited by Darwin: "I now admit [...] that in the earlier editions of my 'Origin of Species' I perhaps attributed too much attention to the action of natural selection or the survival of the fittest. I have altered the fifth edition of the 'Origin' so as to confine my remarks to adaptive changes of structure; but I am convinced, from the light gained during even the last few years, that very many structures which now appear useless, will hereafter appear useful, and will therefore come within the range of natural selection. Nevertheless, I did not formerly consider sufficiently the existence of structures, which, as far

${ }^{1}$ G. W. F. Hegel, Die Wissenschaft der L,ogik, 2nd ed. (1831), Vorrede; Aristotle, Metaphysics, A, 2, 982b.

2 Aristotle, ib., A, 1, 981 ; Hegel, loc. cit.

${ }^{3}$ D. G. Ritchie, Darwin and Hegel (1893), p. 47. See also the discussion of Platonic emanation in Hegel, pp. 51f., and the influence of Goethe, pp. 43ff.

4 William Wallace, Prolegomena to the Study of Hegel's Philosophy, etc. (1894), pp. 118-120.

5 Kuno Fischer, Hegels Leben, Werke und Lehre [Geschichte der neueren Philosophie, Vol. 8], 2nd ed. (1911), pp. 221ff.; T. L. Haering, Hegel, Sein Wollen und Sein Werk, Vol. 1 (1929), pp. 313ff., 382ff., and passim, has brought out the organic and social side of Hegel's developmental thought, pp. 723ff. the physical and mechanical side. Cf. also Ernst Cassirer, The Problem of Knowledge (1950), pp. 170f., for the biological side of the matter. (Here the figure of Ernst Haeckel is not well represented; for his Social Darwinism cf. Daniel Gasman, The Scientific Origins of National Socialism, 1970.) 
as we can at present judge, are neither beneficial nor injurious; and this I believe to be one of the greatest oversights as yet detected in my work."1

The interrelation of structure and adaptive change expressed by Darwin is the dialectical interrelation of being and becoming made into a concretion, whereas it had been conceived only potentially as such by Hegel, actually as an abstract potentiality. Marx developed this side of Hegel. His relation to Darwin was already posited by the anti-teleology in nature that was common to both men. Darwin argued against the notion that natural selection induces variation within species; and against the notion that selection implies conscious choice or volition. His answer to these objections was that natural is a false term. "It has been said that I speak of natural selection as an active power or Deity. [...] So again it is difficult to avoid personifying the word Nature; but I mean by Nature, only the aggregate action and product of many laws, and by laws the sequence of events ascertained by us." ${ }^{2}$ Marx wrote in a letter to Engels that Darwin's book on "Natural Selection" contains the "natural historical foundation for our viewpoint." 3 And in a letter to Ferdinand Lassalle, Marx asserted: "Despite all deficiency, here the death blow of 'teleology' in natural science has not only been struck, but the rational meaning of teleology has been empirically set forth." 4

Marx contributed substantively to the theory of development of man from the rest of the animal kingdom, and to the theory of the development of man as such, in The German Ideology, the Communist Manifesto, the Critique of Political Economy, Capital, Theories of Surplus Value, i.a. However, he remained rather external to the developments in biology, following them closely, but from without. He separated Darwin's natural from his social philosophy. Thus, he criticized Darwin for taking over Malthusian ideas of population and human society, without altering his evaluation of Darwin as a biologist; it was as a natural philosopher that he appreciated Darwin.

Engels, on the other hand, formulated positions internal to biological

${ }^{1}$ Charles Darwin, The Descent of Man (Modern Library, New York, n.d.), pp. $441 \mathrm{ff}$. In the twentieth century Darwin's thought has been re-appraised, but its meaning has not been substantively changed by Jacques Monod, Le hasard et la nécessité (1970), who has brought out as the conditions of organic systems: telenomy, autonomous morphogenesis, and reproductive invariance. It is the combination of these which expresses concretely what Darwin intended by structures "neither beneficial nor injurious".

2 Darwin, The Origin of Species, op. cit., p. 64 (see preceding note).

${ }^{3}$ MEW, Vol. 30, p. 131, letter dated December 19, 1860.

4 Ib., p. 578, letter dated January 16, 1861. 
theory of evolution. Engels did not examine the interrelations of preservation and variation of species which Darwin had arrived at in his later expressions; this might have been formulated as a dialectical opposition and transition by Engels had he done so. Instead he took up only the causes of repeated individual variations, which he accused Darwin of having neglected. ${ }^{1}$ Engels's Dialectics of Nature reports the same viewpoint. The emphasis throughout is upon becoming, in abstraction from the relation to being. In the latter work, moreover, Engels carried the discussion into a field from which Darwin did not separate himself with sufficient care: that of Social Darwinism. But the criticism made by Engels of the latter doctrine was poorly formulated, for he wrote: "Even by itself the conception of history as a series of class struggles is much richer in content and deeper than merely reducing it to weakly distinguished phases of the struggle for existence." 2 This is indeed but a mild attack on Social Darwinism as to its form. As to its content, it misses the point. It is not that Social Darwinism is comparatively poorer and shallower in its conception of history than is the doctrine of the class struggle. It is toto coelo apart from the doctrine of class struggle, for each doctrine starts from different premisses as to the nature of man and of society, their interrelations, etc.

Both in its direct and ancillary developments, the doctrine of human evolution, including the social, is related only in part to scientific materialism, or to the dialectic in concrete form, in the work of Engels. He adopted a unilinear viewpoint in evolution, wherein he was stricter than was Morgan. The latter introduced on occasion some considerations of multilinear evolution. Thus in a broad way, the New World and the Old proceeded in his depiction along different lines, for he found the New World before its discovery to have had no domestication of animals. He therefore sought for equivalent forms between the two hemispheres. Marx added nothing of his own to this side, but noted it down. Morgan made an occasional point of lateral influences from one line of development to the next: he was to a very minor extent a diffusionist. Marx noted these cases, and added some material of his own, in a favorable way. These lines of thought are lacking in Engels's Origin of the Family. ${ }^{3}$

The origin of the family is no doubt the weakest side of Engels's book. Cunow was among the first to attack it on the ground of the

1 Friedrich Engels, Anti-Dühring, E. Burns tr. (New York n.d.), pp. $80 f$.

2 Engels, Dialectics of Nature, op. cit., p. 210.

${ }^{3} \mathrm{Cp}$. The Ethnological Notebooks, Introduction, passim. 
weakness of presentation of the evolution of the family. ${ }^{1}$ Duncker, from the side of the German Communist Party, adopted the same viewpoint as Cunow. ${ }^{2}$ Marx took over the system of the family from Morgan, with but few expressions of dissent. Morgan regarded the patriarchal family of the ancient Hebrews and Romans as being exceptional, off the main line of the evolution of the family, ${ }^{3}$ thereby opposing Henry Maine, and being in turn opposed by M. Kovalevsky. Engels adopted a simple system of the evolution of the family, which proceeded from the matriarchal to the patriarchal, without reference to the Hebrew and Roman variant, as in Morgan. In the fourth edition of his Origin, Engels took over the evidence of Kovalevsky in reference to the patriarchal family, ${ }^{4}$ but as the comparison of the first and fourth editions shows, Engels did not change his view in the light of Kovalevsky's publication, but fitted the latter in without alteration of his original position. He did not bring together the opposed systems of Morgan and Kovalevsky.

While Duncker criticized the position of Engels on the evolution of the family, he found praise for Engels's depiction of the evolution of the state. Lukács, on the contrary, found no fault in his early work with the exposition of the family by Engels, but criticized his depiction of the formation of the Athenian state. Engels had found the development of the state among the Athenians a particularly typical model of state formation in general, his reason for this being that it proceeds in a pure way ("ganz rein") without the admixture of external violence. ${ }^{5}$ Lukács protested that this is "not wholly accurate and wholly untypical for the transition at this stage of development". ${ }^{6}$ The charge against Engels is again that of simplification. Engels had a more complex point in view, which needs elaboration, for his presentation at this point is too much condensed. The theory of the formation of the state by conquest was widely adhered to at that time; shortly thereafter L. Gumplowicz and F. Oppenheimer were to write on the formation of the state from this standpoint, which leads to the force theory. Engels had already attacked the latter theory in his work, Anti-

${ }^{1}$ Heinrich Cunow, "Die Okonomischen Grundlagen", loc. cit.; idem, Zur Urgeschichte der Ehe und Familie, op. cit.

2 Hermann Duncker, Vorbemerkung, in F. Engels, Der Ursprung, etc. (1931).

3 Morgan, Ancient Society (1907), p. 475. Cf. also Part III, Ch. 1. Here Morgan rejects, as Darwin had, any thought of design or teleology.

4 Engels, Origin, op. cit., pp. 51ff.; MEW, Vol. 21, pp. 62ff. C.. M. M. Kovalevsky, Tableau des origines et de l'évolution de la famille et de la propriété (1890).

${ }^{5}$ Engels, Origin, op. cit., p. 107; MEW, Vol. 21, p. 116.

- Lukács, Geschichte und Klassenbewusstsein, op. cit., p. 422. 
Dühring. Internal forces in the process of state formation are clearly shown as economic by Engels, external factors make the case unclear, complex. The charge by Lukács of simplification is partly justified, but evidently there is more involved than that which he has contributed; Lukács, too, had simplified. Engels had posited an abstraction, and thereby had simplified; we will consider some of the issues related to Engels's abstraction below.

In the discussion of the origin of the family and the state by Cunow, Bernstein, Duncker, Lukács, the middle term posited by Engels has been lost to view. Kovalev's contribution is no different, for his concern was with the "theoretical" and "political" side of Engels's work, and not the role of the economic factor in the study of classical society. ${ }^{1}$ Now Engels's treatment of the origin of private property is distributed through his discussion of the other topics: after a brief outline of the prehistoric cultural stages of savagery and barbarism, he divided his book into chapters as follows: the Family, the Iroquois Gens, the Greek Gens, Gens and State in Rome, Gens of the Celts and Germans, State formation among the Germans, Barbarism and Civilization. The chapter headings direct the reader's attention to the institutions of the family, gens and state, which alone are mentioned as such. The stages of cultural development and the peoples dealt with are likewise singled out, but the institutions of property are to be found neither in the chapter headings nor sub-headings; aside from the reference to private property in the title of the book it is mentioned passim in the text. On the other hand, Morgan devoted Part IV of Ancient Society to the Growth of the Idea of Property. Marx in his notes made this fourth part into the second, changing the order that he found in Morgan, and caused his excerpts from this Part to occupy a greater proportion in the whole than Morgan had done.

Yet Engels made the topic of property a central one. Social recognition of paternity, he wrote, "is demanded because these children are to come into the father's property eventually as legitimate heirs."

${ }^{1}$ S. I. Kovalev, 'Znachenie 'Proiskhozhdeniya sem'i' F. Engel'sa v izuchenii antichnogo obshchestva", in: Problemy istorii dokapitalisticheskikh obshchestv, Vol. 5 (1935), Nos 7-8, pp. 87-89.

${ }^{2}$ Engels, Origin, p. 55; MFW, Vol. 21, p. 65. This bears upon the situation at the decline of the gentile society. However, property and its disposition was considered by Engels to be the active factor in social transformation at earlier stages as well. Cf. p. 244, note 2, above. Engels, following Morgan, regarded the family as the active principle, systems of consanguinity the passive (Engels, op. cit., pp. 26-27; MEW, Vol. 21, pp. 37f.; Morgan, op. cit., p. 444). This contradicts the idea that property is the active factor, but without resolution by Engels.

Marx, Excerpts from Morgan, The Ethnological Notebooks, p. 112, wrote in 
In the heroic age of Greece, the gentile order began to decline; the evidence for this is patriarchy, accumulation of wealth within the family, unequal distribution of wealth with its reaction, the first rudiments of hereditary nobility; the new acquisition of riches; the sanctification of property as private property; the invention of the state for the securing of the riches, and the perpetuation of the cleavage of society into possessing and non-possessing classes, etc. ${ }^{1}$ In these passages, the objective side of the formation of the state, and the central role of property, its accumulation in private hands, etc., is set forth.

Morgan went over this ground, particularly in Part II, Ch. 10 of Ancient Society. Here he developed the reforms ascribed to Theseus, whom he regarded not as a person but as representing a period; ${ }^{2}$ he referred to the division of Attic society into three classes: "This classification was not only a recognition of property and of the aristocratic element in the government of society, but it was a direct movement against the governing power of the gentes." 3 Marx followed this presentation in his excerpts, adding:

this connection: "Ebenso verhält es sich mit politischen, religiösen, juristischen, philosophischen Systemen überhaupt." (See Engels, op. cit., p. 27.) It is utter nonsense to think that Marx had in mind the family as the active factor, the political, religious (the order is different in Engels), juridical, philosophical systems in general as the passive. The economic factor is implicit here, applied both to primitive and civilized societies without distinction. Engels did not establish the full and proper meaning of Marx in this case. The matter was set in order by Engels in his letter to Joseph Bloch, September 21,1890, which was first published in Der Socialistische Akademiker, Vol. 1, No 19, October 1, 1895 (MEW, Vol. 37, pp. 462-465). It has been commented upon by Th. G. Masaryk, L. Woltmann, Franz Mehring, Hermann Greulich, E. R. A. Seligman and V. G. Simkhovitch. Seligman (The Economic Interpretation of History (1902), pp. 64-65) called attention to the coeval publication of the letter in Leipziger Volkszeitung, 1895, No 250. Engels wrote: "Die ökonomische Lage ist die Basis, aber die verschiedenen Momente des Ubberbaus - politische Formen des Klassenkampfs und seine Resultate - Verfassungen, nach gewonnener Schlacht durch die siegende Klasse festgestellt usw. - Rechtsformen, und nun gar die Reflexe aller dieser wirklichen Kämpfe im Gehirn der Beteiligten, politische, juristische, philosophische Theorien, religiöse Anschauungen und deren Weiterentwicklung zu Dogmensystemen, üben auch ihre Einwirkung auf den Verlauf der geschichtlichen Kämpfe aus und bestimmen in vielen Fällen vorwiegend deren Form." See also Engels to Conrad Schmidt, August 5, 1890 (MEW, Vol. 37, pp. 435-438) and Oct. 27, 1890 (ib., pp. 488-495); to Franz Mehring, July 14, 1893 (MEW, Vol. 39, pp. 96-100); to W. Borgius (not H. Starkenburg), Jan. 25, 1894 (ib., pp. 205-207; cp. p. 580).

1 Engels, Origin, pp. 96f.; MEW, Vol. 21, pp. $105 f$.

2 Morgan, op. cit., p. 265.

${ }^{3}$ Morgan, op. cit., p. 267. 
"The expression by Plutarch, that 'the lowly and poor readily followed the bidding of Theseus' and the statement from Aristotle cited by him, that Theseus 'was inclined toward the people', appear, however, despite Morgan, to indicate that the chiefs of the gentes etc., already entered into conflict of interest with the mass of the gentes, which is inevitably connected with the monogamous family through private property in houses, lands, herds."

Morgan did not cite Plutarch or Aristotle in this connection, the matter was introduced by Marx, together with his opposition to Morgan, as an inserted comment. ${ }^{1}$ Engels omitted these considerations from his presentation of the matter, following the development by Morgan at this point in a straightforward way. But the points raised by Marx are important, aside from the connection that he drew between the monogamous family and private property. First, he disputed Morgan on the relation between the chiefs and the mass of the gentes. Second, the content of the dispute raises not only the objective and public side of the property and governmental relations, but also the matter of interest as a conflict between the chiefs and the mass. Marx did not develop the question of interest in this context, but returned to it in notes which he introduced into his excerpts from Henry Maine. Here he made it clear that the matter of interest has an objective and a subjective side, and that the two are related. ${ }^{2}$

Marx wrote that the state is an excrescence of society at a given stage of social development and when that stage of development no longer exists the state disappears. As to the onset of the process: "First the tearing of the individuality loose from the originally not despotic claims [...] but rather satisfying and agreeable bonds of the group, of the primitive community - and therewith the one-sided elaboration of the individuality."3 As to the true nature of the latter, it is shown first when we analyze the content, which is the interest of this "latter". Marx refers to this individuality in quotation marks, as something that is not, or not wholly, what it appears to be. The individuality is of the individual, it is at the same time other. The interest is two-faced, inner and outer, as is the content of the individual in relation to the form. The content of this individuality is the interest, the interest is in one regard the sub-

1 The Ethnological Notebooks, p. 210.

2 Ib., pp. 292f. 294f., 308f., 310f. The subjective side of interest in relation to the objective side is treated by Marx in Okonomisch-Philosophische Manuskripte, Die Heilige Familie, Grundrisse, and Kapital, Vol. 3, Part 2.

3 Ib., p. 329. 
jectivity of the human individual. Marx continued: "We then find that these interests are themselves again common to certain social groups, are the interests characterizing them, class interests, etc. Thus this individuality is itself class etc. individuality, and these [class individuality interests] all have in the final instance economic conditions at the basis." 1 The internal, subjective content of the individuality is thus turned into the external, social relation of the individual; and this is a matter of social-economic class. The passage of the formality into the content is at the same time passage of the individual interest into its other regard, the group interest, the subjectivity into the objectivity, and the internality into the externality. These are posited in their interrelations, which are themselves complex, for they are oppositions on the one side and constituent elements of the individual and of the social class of which he is a member on the other. The oppositions, again, are those between social classes, between individuals within the classes, and as between classes. Finally, the interests are oppositions within the individual that they have constituted in this way.

Engels, for his part, introduced as the subjective factor in history unadorned greed (platte Habgier) which he held to be "the driving soul of civilization from the first day down to the present". ${ }^{2}$ On the one side,

$1 \mathrm{Ib}$.

${ }^{2}$ Engels, Origin, p. 161; MEW, Vol. 21, p. 171. Earlier, at the end of Ch. 3 (The Iroquois Gens) Engels wrote: "The lowest interests - mean greed, brutal sensuality, filthy avarice, selfish theft of the common wealth - consecrate the new, civilized, class society; the most despicable means - stealing, violence, perfidy, treachery - undermine the old classless society and bring about its fall." (MEW, Vol. 21, p. 97) Here all the subjectivities are gathered together. It is not that the subjective judgment of Engels has intervened, for this is a noble inspiration; rather, the motives attributed to those who separated from the ancient classless group are entirely subjective, and the process of undermining and overthrow of the gentes is depicted by Engels in entirely subjective terms. The objective side - accumulation of property, changing social relations, changing relations to nature - are listed elsewhere by Engels; they are listed in a somewhat perfunctory manner, taken from Morgan. They are not interrelated among themselves, nor are they related to the subjective factors. The listing of the latter is nevertheless a notable service by Engels, for generally those who call themselves Marxists are contented with seeking out the objective factors alone, the "iron laws", etc., as though mankind was without an internality. The interests are likewise listed by Engels on their subjective side alone. As we have seen, they were related as both subjective and objective by Marx; most so-called Marxists treat exclusively of the objective side of the interests. Again, we are in Engels's debt for having recalled this side of human life in society.

Engels had taken up the problem of greed in an earlier context: "The riches of the neighbors excites the greed of peoples to whom the amassing of wealth 
Engels was concerned not only with the external face of man, but with his internal life as well. On the other, the matter of this proposition remains to be interrelated with the objective influences in history.

Engels, although he actively took up the study of ethnology only occasionally, had a sense of the development of the field, and in this was Marx's superior. Engels wrote that Morgan's schema could only be provisionally accepted, and that it would last only so long as no important new material was added to the developing science. ${ }^{1}$ As this is normally to be expected, his classification could not long be expected to hold. This fine sense of problem was purely theoretical, however, for it led to no changes in the general theoretical conception of The Origin of the Family from 1884 to 1891. During that time, beside the works commented by Engels there appeared those by $F$. Boas on the Eskimos, Boyd Dawkins on prehistory (which Marx may have excerpted: this cannot be traced down at the Institute at Amsterdam), G. De Mortillet, A. H. Lane-Fox (Pitt-Rivers), S. Reinach, A. H. Sayce, F. Seebohm, W. Robertson Smith, and others. Engels followed the work by Dawkins predominantly in his essay Zur Urgeschichte der Deutschen. ${ }^{2}$

Marx's excerpts were taken from books published between 1870 and 1880. There was much activity, but the dominant figures in the relevant fields in England were Charles Darwin and Herbert Spencer, to both of whom Marx sent copies of his work, Capital. They had already expressed their positions in regard to the study of man and society. The impact on Lubbock of Darwin is known. The developments were followed closely by Marx when Darwin's work first appeared, for he commented on Darwin in letters to Engels and Ferdinand Lassalle at that time, and also in notes in Capital, etc. The subsequent develop-

already appears as one of the primary aims in life. They are barbarians: gain by plundering is held by them to be simpler and indeed more honorable than by work." (ib., p. 149; MEW, Vol. 21, p. 159) Here we must translate greed from the motivation or interest of the individual psychology to that of the group. This is difficult, and the older attempts by Wilhelm Wundt and Emile Durkheim to do so have not been satisfactory. More recently the ethnological literature has tended to keep individual psychology on one side and group relations on another. Psychological anthropology today appears to take the group phenomenon as external to the individual, as cultural patterns, shared values, shared attitudes, or the like, without raising the question of how the external factors are internalized by the individual, or the internal factors, motives, etc., externalized in the group constitution and relations. See A. F. C. Wallace, Culture and Personality (1961), pp. 29ff.: The Psychic Unity of Human Groups.

1 Ib., p. 19; MEW, Vol. 21, p. 30.

2 William Boyd Dawkins, Early Man in Britain (1880); Engels, "Zur Urgeschichte der Deutschen", in MEW, Vol. 19, pp. $425 \mathrm{ff}$. 
ment, as it influenced the work of Lubbock, E. Ray Lankaster, and others at the time was not commented upon by Marx. Engels's problematics, on the other hand, remains a decisive contribution to ethnology, touching as it does on the interrelation of data, their interpretation, and the theory.

Engels reproduced the first edition of The Origin intact through the second and third editions. For the fourth edition (1892) he introduced, aside from substitutions in single phrases or sentences passim, considerable changes in Chapter 2 (The Family), and in Chapter 7 (The Gens among the Celts and Germans). The changes in the second chapter incorporated his further studies of Maxim Kovalevsky, whose book on the outline of the origins of the family appeared in 1890, of Heinrich Cunow on ancient Peru (1890), of Fison and Howitt on the Australian aborigines (1880), as well as other materials from older writers: A. Heusler on the medieval Germans; Bachofen on the matriarchate, 1861; Maine, Ancient Law, 1861; Charles Fourier; and further references were added for the fourth edition from Homer, Euripides, the Niebelungen Saga, etc.: an increase in the chapter of one-third in its total size. The changes in Chapter 7 included materials added from Kovalevsky, Grimm, and from Old Nordic lays. The materials from Fison and Howitt ${ }^{1}$ were added by him in consciousness of the programmatic position at the beginning of his book. Nevertheless, none of these new materials, although important in themselves, gave Engels ground to change the schema as a whole. Yet Kovalevsky's material on the system of evolution of the family was different from that of Morgan. Engels, in terms of his own scientific program, ought to have given the reasons why he opted for one side in the debate and not the other. V. G. Childe made an attempt to work out a new system, on the basis of the general theoretical disposition of Morgan and Engels, in the light of new data added to anthropology between the end of the nineteenth and the middle of the twentieth centuries. ${ }^{2}$

\section{Evolution of Society through Stages and Sub-Stages, 2}

The next question that will be considered in which the work of Marx and Engels is compared in the ethnological field relates to the stage of the evolution of human society in the transition to civilization, or politically organized society. Morgan had written of the liberty,

${ }^{1}$ Ib., pp. 37 ff. ; MEW, Vol. 21, pp. 48ff., citing Lorimer Fison and A. W. Howitt, Kamilaroi and Kurnai (1880).

${ }^{2}$ V. Gordon Childe, Social Evolution (1951). My own research has shown that a system of kinship, the Omaha, may be evolved in more than one way. 
equality, fraternity of the ancient gentes. ${ }^{1}$ There followed, in the dissolution of the gens, the formation of military democracy, in which Engels followed him closely. ${ }^{2}$ The matter concerns the basileus, the military commander in Homeric Greece, sometimes rendered as "king". Morgan had distinguished between civil and military chiefs in the status of barbarism, having cited the examples of Iroquois, Aztec and Greek leadership. The Homeric Greeks in his analysis had the military commander on one side, the governmental power other than military, juridicial and priestly on the other. Morgan put this form of rule into a particular sub-stage of the end of the Upper Status of Barbarism, in which he was followed by Engels. It has so appeared in subsequent writings as well.

Marx put the concept of Homeric social organization in this way. Each gens descended from a god, the tribe-chiefs already from a more eminent one. Even the personally unfree, as the swineherd Eumaneus and the cowherd Philoitios are of divine descent dioi or deioi, and this in the Odyssey, hence at a much later time than the Iliad; the name Heros is applied in the Odyssey to the herald Mulios, the blind singer Demodokos, etc. Koiranos, which Odysseus applies to Agamemnon alongside basileus, still means only commander in war there. " $\beta \alpha \sigma \iota \lambda$ zí $\alpha$, angewandt $\mathrm{v}$ [on] $\mathrm{d}[\mathrm{en}]$ griech[ischen] Schriftstellern für $\mathrm{d}[\mathrm{as}]$ homerische Königtum (weil generalship his chief feature) mit

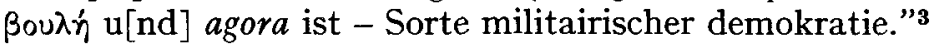

This is a different formulation from Morgan and Engels. "Military democracy" had been set forth as a formal category by Morgan and Engels. Marx, however, conceived the military democracy as a kind of comparison, in passing, not a definite sub-period or stage of human development. The office of military leader, assembly and council together made up a sort of military democracy. This looser formulation implies noncommitment to the periodization, questioning of it in the form that it had come to Marx. While geological stratification was successfully being developed in the latter part of the nineteenth century, and its evidence in Morgan's thinking is unmistakable, Marx held himself back from this and transformed it into an analogical mode.

1 Morgan, op. cit., pp. 561ff. Cf. Engels, op. cit., pp. 162f.; MEW, Vol. 21, pp. 172f. Marx, The Ethnological Notebooks, p. 139, noted Morgan's passage on property. When Morgan commented that the civilization (of property) is but a fragment of man's time on earth, Marx wrote: "und zwar sehr kleines"; but he assigned no special place to this thought. Engels turned this utopian set-piece of Morgan into his own peroration.

2 Morgan, op. cit., pp. 126, 256, 259, 282 ; Engels, op. cit., p. 96.

3 The Ethnological Notebooks, p. 207. Bertrand de Jouvenel, Power (1952), Ch. 5, continues the distinction between $d u x$ and rex. 
(Engels applied the method of the paleontologist Cuvier in an organic model of the reconstruction of society, which Marx likewise did not wholly accept.) ${ }^{1}$

\section{IV}

\section{FROM PHILOSOPHICAL ANTHROPOLOGY TO EMPIRICAL ETHNOLOGY}

In the sixth thesis on Feuerbach, Marx wrote: "Feuerbach resolves the religious essence in the human essence. But the human essence is not in-dwelling abstraction of the single individual. In its actuality it is the ensemble of the social relations." ${ }^{2}$ The social relations are the opposite of the isolated individual presupposed in the figure of Robinson Crusoe and in the classical economists. Marx continued to oppose the Robinson figure, the Robinsonade; Hilferding chose this as his central point in the attack against Böhm-Bawerk, Sweezy identified this point of Hilferding's in his note on the Böhm-Bawerk versus Hilferding controversy. ${ }^{3}$

The isolated individual is not only the figment of the classical economists, and the subjective theory of value in economics, it is

1 For Marx on Cuvier, cf. Kapital, Vol. 1, op. cit., p. 478. See his letter to Engels, March 25, 1868, in Selected Correspondence, 2nd ed. (1965), p. 201. See also, in reference to Engels and Cuvier, The Ethnological Notebooks, Introduction; Engels, Origin, op. cit., p. 27; MEW, Vol. 21, p. 38.

2 MEW, Vol. 3, p. 6. Engels published these notes of Marx, written early in 1845, as an appendix to his own Ludwig Feuerbach. Engels made insignificant changes in the text quoted (capitalization, semi-colon, etc.). N. Rotenstreich, who has written a learned and balanced commentary on the Theses, has rendered the last quoted word, Verhältnisse, as "conditions"; this is not appropriate, being neither apt nor usual. Here the meaning "relations" is restored. The reason for this is seen in Marx's continuation of the sixth thesis: "Feuerbach, who does not go into the critique of this actual essence, is therefore forced: 1 . to abstract from the historical course and fix the religious temperament for itself, and to presuppose an abstractly - isolatedly - human individual. 2. The essence can therefore be taken only as 'genus', as inner, silent universality, which binds many individuals naturally together." The abstraction that Feuerbach made posits an isolated individual, the opposite of the individual in his social relations. The isolation is not the opposite of a condition, its overcoming is the establishment of a relation. Marx opposed Feuerbach's "genus" for the latter had conceived this as the universal which naturally binds the many individuals. According to Feuerbach, the bond is not social but natural (Marx's emphasis), to which Marx opposes the social. Man is an ensemble of that which is not isolated but linked together, related. The linkage then serves as the condition sine qua non of social life; but it must first be established. Rotenstreich omitted this step (Nathan Rotenstreich, Basic Problems of Marx's Philosophy (1965), pp. 69-78).

2 E. v. Böhm-Bawerk, Karl Marx and the Close of his System, and Rudolf Hilferding, Böhm-Bawerk's Criticism of Marx, P. M. Sweezy ed. (1966). Cf. Hilferding, pp. 132f., and Ed. Introd., p. xx. 
posited by the theory of the social contract as well. The latter proposes that (mythical or real) individuals contracted with each other to form a society for ends that they had in view: peace, surcease from fear, material improvement, longer life. The individual exists prior to society, and his existence is a prior condition of its establishment in the theory of the social contractarians Hobbes, Spinoza, Rousseau, down to Herbert Spencer. The idea of Marx is that man exists only in society, which is a condition of his human life, just as man in his biological actuality and his human potentiality is a condition of society, which does not exist without individual people. Marx implied that by the phrase "human essence", which is taken not in its abstraction but in its concretion, not in its innateness but in its elaboration. In its concretion and its actuality it is the ensemble of human relations, the opposite of an in-dwelling essence as an abstraction. Too much can be made of this, for Marx eschewed an ontology of the human. He went only as far as the identification of man in society, leaving it to others to argue that the human being is only a social being, that the social in the individual is the constituent of his human being.

Marx advanced the idea of the social in man in a number of his writings: the Grundrisse, the Critique of 1859 , Capital, etc. ${ }^{1}$ Man is and can be only a human being in society, and this was made into a slogan by the early nineteenth century utopian socialists and communists, in opposition to the individualist doctrine of society and economy of those who were then in power in Europe. Marx and Engels made their doctrine explicit in the title, Communist Manifesto, Engels again in his Socialism Utopian and Scientific. The terms socialism and communism were not strictly separated, and Engels averred that the choice of one or the other was made by Marx and himself for a practical and not theoretical reason, to separate themselves from the followers of Robert Owen, Charles Fourier, etc. ${ }^{2}$ Nevertheless, they were and remained socialists, without making a theoretical separation of the term from communist.

Ferdinand Tönnies, while he was not close to Marx or Marxism, acknowledged his debt by a half-dozen references to the man and his work; Tönnies's book Gemeinschaft und Gesellschaft, ${ }^{3}$ anglice: Com-

1 Some of these places are given in Krader, "Critique dialectique de la nature de la nature humaine", loc. cit.

2 From the Preface to the English edition of The Communist Manifesto (1888).

3 Ferdinand Tönnies, Gemeinschaft und Gesellschaft (1887). Lukács, op. cit., p. 310, has brought out the relation of Tönnies to Marx regarding the impact of social, economic and technical relations upon the form and content of ideas, their history, etc. A defense of Marx's solution of the average rate of profit, in connection with his theory of value in economics, against the attacks by the 
munity and Society, expresses the core of the opposition to individualism of the political movements, for he starts from the premiss that man is a social animal, as did his other master, Henry Maine. Maine, however, is straightforward in positing that man is a social or communal being to start with, proceeding then from a form of life as status to a contract form. In the status form, which gave rise to Tönnies's Gemeinschaft, the individual is formed as a social entity; but in Maine this is the Family. Tönnies posits the will (Wesenville) in the Gemeinschaft, borrowing the concept of the will from the doctrine of the individualists. Tönnies brought together the terms Socialism and Communism, but not in a way that brings out the common etymological basis of Gemeinschaft and Communism and of Gesellschaft and Socialism. ${ }^{1}$ This philosophical note is more than a curiosity, however, because community, commune, Gemeinde, Gemeinwesen, etc., are separated from Gesellschaft by Marx as a general rule; he also changed Aristotle's definition of man to read "Stadtbürger" instead of "social animal". Great attention was given to the Gemeinwesen in Marx's Grundrisse and in Capital, passim. The excerpts from Morgan, Maine and Phear add materially to what we already have from Marx in this domain.

\section{1: The Primitive and Peasant Community}

The concern of Marx with the question of the peasant community, the collective communal institutions of the primitive societies, and the

Austrian and German economists (as Böhm-Bawerk, see above), was included in the 1911 edition (Part $1, \S 40$ ). His contribution, however, as compared with that of $\mathrm{L}$. von Bortkiewicz, his contemporary, has passed more or less unnoticed, and with reason. See P. M. Sweezy ed., Introd., loc. cit.

1 Tönnies, op. cit., Part $4, \S 9$. The relation of the -ism to the practice, of the ideology of the commune to the social reality, of the ideology of society to the social practice and relations of society, is implicit in the terms communism, socialism. Tönnies made a step forward by positing his part of the problem. He cannot be said to have advanced his conception of it very far, still less to have resolved the relation between the fact of community and of society on the one side, the ideology raised upon those facts, communism and socialism, on the other. In the period since he wrote, no one else appears to have done so. The opposition of community and society is today somewhat clearer than it was at the time that he wrote, the opposition of individualism and communism/socialism is no clearer. The relation of communism to socialism was left unclear, pragmatic, by Engels, and there it rests. - Cp. Th. G. Masaryk, Die philosophischen und sociologischen Grundlagen des Marxismus (1899) (1963), p. 185. Here, Feuerbach's "Gemeinmensch = Communist"; Marx's "Mensch ist "Gesellschaftsmensch"'. But the parallel of Gemeinschaft and Gesellschaft was overlooked (ib., p. 203). Further, Masaryk attributed to Marx the position that the individual consciousness is illusory, the collective consciousness alone is real (pp. 184ff.). Contra Masaryk: Antonio Labriola, Essais sur la conception matérialiste de l'histoire, 2nd ed. (1902), pp. 279-313 (Rivista Italiana di Sociologia, May 1899). 
place of private, individual human existence in society has a number of facies, one of which has been singled out by the discussion of the Asiatic society or the Asiatic mode of production. The Asiatic society has for its basis the peasant community which in turn comprises a number of collective institutions within itself. Marx considered that these institutions are of the lower form of communism, which by its study will tell something of the higher form still unknown, and so expressed himself in drafts of his letter to Zasulich, ${ }^{1}$ in the Preface to the Russian edition of the Communist Manifesto (1882), and in the excerpts from Morgan. ${ }^{2}$ The viewpoint of Morgan was that the property career of man had a distorting effect on the human intellect and was short-lived, a view not alien to Marx's own. Therefore the study of the ancient gentes, of the Oriental communities and of the European peasant institutions were taken up by him. In addition, since these communities had lasted from ancient times down to the present, they provided a pointer to another direction of human development than through the path of capitalism. This is a plural approach to the question of man's present and future, an anti-determinism, which his studies of the Indian and Russian peasants indicated. ${ }^{3}$

Marx studied the communal form of social life not only in its ancient mode, but added the data from peasant communities as well, his most important source was G. L. Maurer, from whom he took an immense amount of notes on Germanic antiquity; in addition, he studied a score of writers on the Slavic peasant institutions, and the Oriental communities; the writings of Maine and Phear are included here. (Phear's data are most detailed, but show few evidences of collective communal organizations or institutions; moreover, his reconstructions of the past are speculations.) Marx's studies of the peasant communities are surveyed in The Ethnological Notebooks ${ }^{\mathbf{4}}$ here we will deal with some ancillary questions.

The first of these concerns the distinction between community (or commune, Gemeinwesen, etc.) and collectivity. Such communities may be rural or urban; indeed it is the characteristic of nations, societies, civilizations whose composition is predominantly peasant that the urban institutions be strongly influenced by the rural.

\footnotetext{
1 "Briefwechsel zwischen Vera Zasulič und Karl Marx", D. Rjazanov ed., in: Marx-Engels Archiv, Vol. 1 (1926), pp. 309-342.

2 Marx's excerpts from Morgan, The Ethnological Notebooks, passim.

${ }^{3}$ S. I. Kovalev, loc. cit. (cf. p. 252, note 1, above), p. 96, expressed the objections to the theory of the Asiatic mode of production then current in the Soviet Union: it was the theory of counterrevolutionary Trotskyism; and it served as the basis for the historical development of the Orient as separate, "original".

- The Ethnological Notebooks, pp. 58ff.
} 
Thus, in nineteenth century Russia, the presence of producing collectives (artels) of peasant origin has been described. ${ }^{1}$ Collective institutions of production or consumption are well-known both in eastern Europe down to the nineteenth and even twentieth centuries, in the ancient history of Greece and Rome, in the ancient Orient, and elsewhere. ${ }^{2}$

The problem of the communal collectivity was raised in the discussion of Caesar's Gallic Wars, Tacitus's Germania and the Germanic Mark, Markgenossenschaft, Russian mir, South Slavic zadruga, and the Oriental commune. He ended his notes from Morgan with the addition of a series of excerpts of his own from Caesar, Tacitus and Tacitus's commentator, Justus Lipsius, which are not found in Morgan, and which bear in major part on the collective institutions of the ancient Germanic peoples. That the problem of the commune in India was in his mind is to be seen from a slip of the pen in which he refers to Phear's "Aryan Commune" instead of Aryan Village; this is partly what he went to the study of the village for. ${ }^{3}$ The Morgan excerpts include materials added by Marx on the South Slavic zadruga, Russian mir, and related institutions, and in the Maine excerpts there are likewise discussions of communal life.

Marx had only begun the examination of the differences between public and private relations and practices in the ancient communalcollective organization; likewise, in the dissolution of the ancient gentes, the transition from status to contract was taken by Marx as a given. The matter of public versus private property in the state of civilization is opposed to collective enjoyment in common in the primitive state. The ancient gentes were taken by Marx, as they were by Maine and Morgan, to be collectivities; the difference being that Maine celebrated the rise of the individual, individual property ownership, legal and moral position, Morgan deplored the rise of property, the preponderant concern with property in civilization, and the detrimental effect which this has on man and his mental regimen. Engels gave his accord to Morgan with all his heart; Marx did not dissent.

The identification of the conception of man as a creature of society is found in a number of writings of Marx in the early 1840s. He later took up the problem as we have seen, but only briefly in regard to primitive society. However, the life in the primitive community, in which the

1 L. Krader, "Transition from Serf to Peasant in Eastern Europe". in: Anthropological Quarterly, Washington, Vol. 33 (1960), pp. 76-90.

${ }_{2}$ The literature on this subject is very large. For Russia see Carsten Goehrke, Die Theorien über Entstehung und Entwicklung des "mir" (1964).

${ }^{3}$ Excerpts from Lubbock, The Ethnological Notebooks, pp. 343, 421 
distantiation from nature was neither great nor profound, and in which man "has not yet severed the umbilical cord that unites him with his fellow men in a tribal community", was closely bound to the earlier conception, and was taken up again in the notebooks containing his excerpts from the works of Maurer, Kovalevsky, Morgan, Maine, Phear, and Lubbock. The relation of the primitive community to the individuality of the human being was posited by Marx not only in opposition to Maine, but also to Hobbes and Rousseau. The transition from the primitive community was taken up for itself and for the understanding of the problem of social transition, of the prior state of primordial communism, the subsequent state of society divided into classes, and the lessons of primordial communism for the transition to communism under civilized conditions. The basis of the transition from the primitive community had been connected to the development of private property by Kovalevsky, who posited a primordial life in a communal village or kincommunity owning land in common and repartitioning it at intervals. Influx of more distant kin and new settlers brought about an unequal distribution disfavoring the distant kin and the newcomers. The closer kinsmen, who were the older inhabitants, had larger (or more accessible, more fertile? - Kovalevsky here simplified) tracts of land and in selfprotection converted these into private holdings, anticipating a decline in their fortunes if others were accorded equal rights. ${ }^{1}$ Kovalevsky then raised a theory of priority of title over limited terms of first 20 , then 10 years, leading to lawful acquisition of land rights in perpetuity. Marx commented: "Much simpler to say: Unrest over increasing inequality of portions [of land] which by lengthening duration meant various other inequalities of property ownership as well, claims, etc., in short many other social inequalities, must call forth a tendency on the part of those thus privileged to entrench themselves as possidentes."2

Marx accepted the notion of primordial village kin-communities, communal land ownership, redistribution of land at intervals by families, and some advent of distant kinsmen or other newcomers. Inequities of land distribution created unrest thereby, and private property was established by the older settlers with prior claims to land as a defense. (The defense was twofold, first to maintain the prior rights, second to prevent incursions in times of trouble.) The settlement in kin-groups, however, presupposed the spatial separation of branches of the kincommunities, the spatial being related to the distance in time from the

1 M. M. Kovalevsky, Obshchinnoe Zemlevladenie (Moscow, 1879), pp. 93f. On landownership in common (in principle) down to English period in India, see Marx, Excerpts from Kovalevsky, op. cit., IISG, Notebook B 140, p. 73.

${ }^{2}$ Marx, ib., pp. $34 f$. 
original settlement. This is common ground between Kovalevsky and Marx. Kovalevsky, however, introduced the factor of consciousness of kinship as the efficient cause, rather than the fact of separation of the various branches of the descent lines. Marx opposed the introduction of the factor of consciousness into history in this way. ${ }^{1}$

The settlement of the kin-groups in villages, the influx of outsiders, the response of the earlier settlers created the social and economic inequities according to Marx's reading of Kovalevsky, wherein he set aright the mystical inversions and pared away the pleonastic intrusions of the latter. Social and economic inequity is thus based upon factors of society and economy that are internal to the kin-community, together with the external relations: branching out of collateral lines of common descent, the return of some of these, and other migration factors. The social arrangements leading to private property are introduced in order to protect the inequities already extant in the distribution of social wealth, or to protect those to whom the advantage from these inequities already accrued against anticipated social unrest. (Since the communities are close to nature, the natural advantages of one community against the next will increase the internal inequities, causing the further flow of families from one to the other.)

The theory of the decline of primordial equality, fraternity and communism through action of internal factors is to be taken in conjunction with the factor of exchange between communities, whereat commodities and commodity exchange begin their historical career. ${ }^{2}$ This is a dialectical moment opposite to the first, for it involves the internalization by the given community of an external relation, exchange between communities; the internal relation of commodity production is thereby established. In the first theory, on the contrary, the explanation of the rise of the inequities rests on the externalization of internal relations, and their reinternalization by in-migration, return of collateral kin, etc. The internal and external factors were not brought together by Marx, for his studies were cut short by his death.

The explanation of the decline of the ancient communities, which was advanced by Engels has already been stated in part: the subjective factors of greed, etc., the objective factor of the accumulation of property in the community. Specifically in regard to the Germanic primitive community, the Markgenossenschaft, Engels likewise reckoned the primordial arrangement to be the ownership and use of land held in common by the village kin-community. The consanguineal unity according to Engels was broken up by increasing population and the further develop-

${ }^{1}$ Kovalevsky, op. cit., pp. 75 f.; Marx, op cit., p. 29.

2 Marx, Kapital, Vol. 1, op. cit., p. 54. See also Marx, Grundrisse, pp. 75-77. 
ment of the folk. The system of mother village and colony villages arose out of this primordial unity. ${ }^{1}$ The same notion was posited by Engels in a later study on the Mark; here he went as far as to consider that the entire folk was originally a single Markgenossenschaft, whence the system of mother and daughter villages arose. ${ }^{2}$ In his comment on the beginnings of commodity exchange depicted by Marx, Engels introduced the factor of the excess (social) product into the beginnings of exchange. ${ }^{3}$

The factor of increasing population and that of the further development of the folk, whatever that means, are actually or apparently internal factors of social historical development. The system of mother and daughter villages appears to be a factor of external relations in this development, but was taken by Engels as a social movement of a single system internal to the entire social life of a single folk. (It is a transition to an external factor from an internal one.) The positing of the excess social product is the transition likewise to an external relation, the exchange of commodities between communities. These factors were not taken together by Engels, but were left here and there. The transitions are neither expressly posited nor are they related to their conclusions, the historical development of separate communities which have arrived at commodity exchange and production, hence alienation of the product, alienation of men from each other and from nature, antagonisms within the communities, which are communities no longer, antagonisms between communities. The transition to civilization, which Engels had posited, is separated from the foregoing relations.

The factors of improved technology, development of the science of mastery over nature, introduction of new breeds of plants and animals, new implements (plough, windmill, metallurgical developments, etc.) are not considered. These may have been implicit in Engels's phrase "the further development of the folk" in his essay Fränkische Zeit, but the phrase is too vague to tell definitely.

Missing in Engels is the interrelation of the various factors of subjective and objective, internal and external, formal and substantial relations of the social life of the primitive peoples. At Marx's death they were left as disjecta membra. We cannot say that Engels brought them together in a dialectical system, although his contributions on both the subjective and the objective sides were richer than following generations have held them to be; those of the generations that followed in his tradition have been rather one-sided, hence have not followed it in general.

1 Engels, "Fränkische Zeit," in MEW, Vol. 19, p. 474.

2 Engels, "Die Mark", in MEW, Vol. 19, p. 318.

3 Engels, "Ergänzung und Nachtrag zum III. Buch des 'Kapital", in: Die Neue Zeit, Vol. 14 (1895-96), Nos 1 and 2, reprinted in MEW, Vol. 25, pp. 897ff.; see p. 906. 


\section{2: A siatic Society and Means of Production}

Marx in both the Phear and the Maine excerpts distinguished sharply between the Oriental and the European historical courses. He ridiculed even the modified attempt by Phear to think in terms of feudalism in Asia, and supported tacitly Maine's depiction of the Oriental monarchy of Runjeet Singh in its contrast with the European. He brought out the same opposition to Kovalevsky's theory of feudalism in traditional India. ${ }^{1}$ Marx likewise made the distinction, as did Phear, between the

1 Kovalevsky had proposed that India, particularly at the time of the Mogul Empire, had a feudal regime in the western European sense. Marx advanced the following against this proposal: "Weil sich 'Beneficialwesen', 'Weggabe von Aemtern auf Pacht' [dies doch durchaus nicht bloss feudal, teste Rom] und Commendatio in Indien findet, findet Kovalevsky hier Feudalismus im westeuropäischen Sinn. Kovalevsky vergisst u.a. die Leibeigenschaft, die nicht in Indien und die ein wesentliches Moment. [Was aber die individuelle Rolle des Schutzes (cf. Palgrave), nicht nur über unfreie, sondern auch ïber freie Bauern betrifft - durch die Feudalherrn (die als Vogte Rolle spielen), so spielt das in Indien geringe Rolle mit Ausnahme der Wakuf] [von der dem romanisch-germanischen Feudalismus eignen Bodenpoesie (see Maurer) findet sich in Indien so wenig wie in Rom. Der Boden ist nirgendwo noble in Indien, so dass er etwa unveräusserlich an roturiers wäre!] Kovalevsky selbst findet aber einen Hauptunterschied selbst: keine Patrimonialgerichtsbarkeit, namentlich bezüglich des Civilvechts im Reich der Grossmoguls." Of the five main points raised by Marx, the first brings in Rome together with Mogul India and feudal western Europe; there is nothing particularly feudal about selling or letting of offices. The fourth point is to the opposite effect: the mystique of life on the land was no more found in India than in Rome; the land was indeed alienated in India to speculators in that commodity. Three remaining points determine the absence in India of fundamental institutions of western European feudalism: serfdom, service of individuals as bailey or Vogt over peasants free or bound (save in regard to the religious foundation, the waqf), and patrimonial jurisdiction, particularly in civil law. One set of arguments points to common features as between India and Rome in the first case including feudal Europe, in the second excluding it. The second set of arguments continues to exclude Indian from European historical practice. The entire direction of Marx's argumentation is toward the separation of Indian from European history. It is not in point, therefore, to think of a general category of feudalism, with one variant of it in western Europe and another in Mogul India. India shares with ancient Rome certain features, Rome is in turn separate from European feudalism as an epoch of society, history, culture, mode of production, etc., and from Oriental society. The entire line of Marx in this matter is against universal schemes of periodization of human history. (Marx, Excerpts from M. Kovalevsky, Obshchinnoe zemlevladenie, op. cit., IISG, Notebook B 140, p. 67. The Russian translation of Marx's excerpts from Kovalevsky, published in Sovetskoe Vostokovedenie, 1958, Nos 3-5, and Problemy Vostokovedeniya, 1959, No 1, is generally sound. It has rendered Marx's phrase "keine Patrimonialgerichtsbarkeit" as "otsutstvie patrimonial'noy yustitsii" (Kovalevsky's phrase) (Sov. Vostokovedenie, 1958, No 5, p. 12; Kovalevsky, op. cit., p. 153). The matter cannot be left there: it is not the lack of patrimonial justice but the lack of the patrimonial jurisdiction in the civil law 
Indian and Western European villages. Marx had followed developments in Asia, particularly in China and India, during the period of his journalistic output in the $1850 \mathrm{~s}$. Regardless of whether the further developments of Asia would bring about a convergence with the European history, he rejected the idea of a common historical course until that time.

Engels had proceeded from the premiss that "At all earlier stages of society production was essentially collective, just as consumption proceeded by direct distribution of the products within [...] communistic communities." The (social) division of labor undermines the collectivity of production. ${ }^{1}$ These are universal rules, from which geographic variation is excluded. Earlier Engels had written of the taming, breeding and herding of cattle in Asia; pastoral tribes separated themselves from the rest of the barbarians in the first great social division of labor. ${ }^{2}$ In the later passage Engels saw as the consequence of the (social) division of labor, the gradual development of commodity production, and exchange between individuals; in the earlier the herds gradually pass into private ownership and exchange between individuals becomes more common. Thus Asia conforms to the general rule for all mankind.

Wittfogel has charged Engels with oscillations for and against the existence of Asiatic society "as a major societal order". The basic attitude of Engels, accordingly, was the acceptance of that society as such in his writings prior to and after the publication of The Origin of the Family, whereas in the latter, Asiatic society as a historical and social category comparable to feudalism etc., disappears. ${ }^{3}$ In Anti-Dühring Engels had affirmed the existence of Oriental despotism, relating it directly to the prolongation of the village communities which have "for

of the Mogul Empire that Marx brought out. The reference to justice is to the abstraction, that to Gerichtsbarkeit is to the concretion.) - On Phear and Maine see The Ethnological Notebooks. These considerations may help to bring to an end any doubts as to Marx's considered and repeated statements that Asian history, society and mode of production are different from the West European. 1 Engels, Origin, pp. 158f. See Part 1 of this Section, above.

2 Ib., pp. 47f., 145f. There is a basis here for multilinear evolutionism, but this was not brought out by Engels.

${ }^{3}$ K. A. Wittfogel, Oriental Despotism (1962), pp. 382ff. Engels avoided reference to an Asiatic particularity in the English edition of the Communist Manifesto (1888). Here, in the first footnote to Ch. 1 he wrote of landownership in common by village communities "from India to Ireland", and related this phenomenon to the gens of Morgan. The emphasis here is therefore on generality rather than particularity. In the Preface to the Russian edition of the Manifesto (1882), written jointly with Marx, the emphasis was placed on the particularity of Russian development, from a "form of the primeval common landownership to the higher form". 
thousands of years formed the basis of the most barbarous form of state, Oriental despotism, from India to Russia".1

Wittfogel's argument is that the Oriental despotism is a form of rulership in society which arises out of the administrative functions of monopolistic control of water supply and hydro-technology generally in early states of Asia, enduring in some cases until the twentieth century; further, that Lenin and Stalin concluded that administrative monopoly of functions of this type created a social category of polity, economy and technology that is applicable to the state-form of the Soviet Union, and therefore suppressed this category of social, historical and economic analysis.

How Engels is to be connected to this line of argument is not established by Wittfogel. He attributes to Engels a "lack of subtlety" reference to Anti-Dühring, although he found that Engels posited the Asiatic society in that work; but Engels is charged with "hiding" that which he had elsewhere so eloquently described, the ruthless methods of exploitation by despotic masters of the functional state, and with having "back-handedly admitted" that his references to civilization excluded the Oriental despotism. ${ }^{3}$ Yet Wittfogel's appreciation of Engels is other than that of Lenin and Stalin. Either Wittfogel has not been sufficiently open with his readers or he has not fully worked out his position for himself. These are formal and external matters concerning the political context, use and target of the arguments. As to the substance of Wittfogel's analysis of Engels, an alternative is to be considered that he has not taken up. The Origin is concerned only with a unilinear evolution, as is the English edition of the Communist Manifesto prepared by Engels in 1888. Engels's Anti-Diihring, the Russian edition of the Communist Manifesto (1882), and the German edition of the same (1890) posit a multilinear path of social development, these were either joint products with Marx or reflect prior positions worked out jointly by Engels and Marx. Engels's work on Marx, Capital, Volume III, shows the same dichotomy: the first part of $\mathrm{Ch} .43$ was worked by Engels on the basis of Marx's materials; here the North American prairies, the pampas of Argentina, and the lands of the Russian and Indian communistic communities are separated from those

1 Engels, Anti-Dühring, p. 206. Engels turned to the phrase "thousands of years" no less than three times in writing of the primitive communities in their relation to the history of India, the Slavs, Russia, and the Oriental despotism generally. Engels, Origin, p. 143, alludes to labor slavery of classical antiquity, and to domestic slavery of the Orient (MEW, Vol. 21, p. 150).

2 Wittfogel, op. cit., p. 384.

3 Ib., p. 386. 
of the (central and west) European farmer and peasant.. ${ }^{1}$ In the articles published by Engels in connection with Capital, Vol. III, the development from the peasant-communal to the capitalist modes of production is expounded, but without variation, in a straight line. ${ }^{2}$

The point is not that Engels, alone, was a unilinear evolutionist, and together with Marx a multilinear evolutionist. The point is that a dialectic of the relation between the one and the many, between the abstract and the concrete, between the general and the particular, was not worked out by Engels. Marx, according to Karl Korsch, worked from the abstract to the concrete and his publications, insofar as they record his fully elaborated positions, express the dialectical relations of these. The dialectic of Engels was, in a number of cases, defective because one-sided. The dialectic of Wittfogel is also defective, one-sided, but in regard to the formation of the state, it is the opposite side of that of Engels. In The Origin Engels posited a "wholly pure" case of the evolution of the state. Engels abstracted from the natural relations, and the relations to the surrounding communities, gentes, tribes thereby; the process of state formation according to Engels was encompassed entirely within the Athenian gentile system, and is accounted for by the dissolution and transformation of the social and economic relations therein. ${ }^{3} \mathrm{He}$ did not take into account man's changing relations to nature in this period of transition from the communal to the political form of social life, nor did he recognize the external relations of economic exchange between communities, or conquest.

Nevertheless, Marx had expressed the opinion that the development of products into commodities arises out of exchange between communities, and not between members of the same communities. ${ }^{4}$ "Commodity exchange begins where communal existence ends, at the points of their contact with foreign communities or members thereof."5 Engels's comment in 1894 was: "Today since the extensive investigation of the original communities by Maurer down to Morgan, hardly a contested fact anywhere."6 The lacuna in the presentation in The Origin is all the more astonishing therefore, since Engels took the Athenian development in its purity of isolation (abstractly) whereas the transformation of products into commodities was the relation between communities, as the economic factor at work during the

1 Marx, Kapital, Vol. 3, op. cit., Part 1, pp. 259-260.

2 MEW, Vol. 25, pp. 906, 910f. (see above, p. 266, note 3).

3 See above, p. 251, notes 5 and 6.

4 Marx, Kapital, Vol. 3, 3rd ed. (1911), Part 1, p. 156.

- Kapital, Vol. 1, op. cit., p. 54.

- Kapital, Vol. 3, ib., note. 
period of dissolution of the ancient gentes and the formation of political society. Thus the case to be made out against Engels is graver than the charge of inaccuracy (Lukács) or that of omission of a geographic variant in the process (Wittfogel). It is that he denied his own canon, and failed to understand, let alone apply, the dialectical grasp of it.

Engels turned his back on two factors. First, the interrelation between communities, gentes, etc., in the transformation from products to commodities. The ancient society does not transform as a pure case into a political society; hence the adversion to Athens as such is theoretically nonsensical to start with, besides being erroneous in fact. Nothing takes place in isolation, but more than that, Marx, who might have provided the canon for Engels's thinking in this matter, argued against the transition of isolated entities to political society in general, whether or not these entities be tribes, gentes, communities, villages, etc. Second, the economic factor has come in during the period of transition to civilization, and not during the period of civilization alone, an important modification of Engels's separation of primitive from civilized man. From these two considerations, a third follows: the transformation from the production of products to the production of commodities in society and the transformation from communal to civilized life do not proceed pari passu, in their external relation; they are interlocked, but the economic interrelation is not worked out by Engels.

Wittfogel's position, on the other hand, is justified by later published evidence from Marx to this extent: Marx continued his opposition to the subsumption of Oriental under European historical categories. The traditional society of Asia was sharply separated from that of classical and feudal Europe by Marx. Wittfogel deals with the early state already formed, as opposed to the state in statu nascendi, which was Engels's problem. Wittfogel presents the gradation of societies, at one end the simpler societies without the state, at the other end the complex societies with the state. The intervening and common factor that runs through the various grades of political development is the evolution of water control, the social institutions for its management, and the technology, proprietary rights, etc., directly associated with it. $^{1}$ These are relations of man to nature in the first place, and the internal and external arrangements that arise out of those relations. The increase in wealth and the accumulation of property; the economic relations of communal to private ownership of the property; the economic relations of transformation of products into commodities; the exchange of the latter as between communities; the social relations

1 Wittfogel, op. cit., Ch. 7, passim. 
internal to the society, as the dissolution of institutions comparable to the ancient gentes described by Morgan and Engels; the subjective factors of the individuals in society and internal factors of the social development were reviewed by both writers; these matters are not taken up by Wittfogel. On the other hand, he discusses the external social factor of conquest in the context of a society already divided into classes, having formed the state, etc. ${ }^{1}$ The dialectical relations of man and the physical environment in the process of formation of complex, classdivided society, and man's relations with his external social environment, are discussed by Wittfogel, but not the internal relations and transition within the society itself that is in the process of formation of its state. This, however, was the primary concern of Marx in his critiques of Kovalevsky, Morgan and Maine; in this Engels followed him. The dialectic of the internal social factors as posited here, as that of the interrelation of these with the external factors, in the formation of the state and its elaboration, is not worked out by Wittfogel.

The ethnological notebooks of Marx stand at the center of the development of philosophical in its relation to empirical anthropology. Within the former, the theory of man as a social being, as interactive in the society, and the society itself as collective originally, in its oppositive relation to the theory of man as an independent, individual being, has long since been posited, but it has not been fully worked out. Within the latter, the development of human society has been seen on the one side as the external relations, on the other as the internal relations of the given society. The relation of the two remains as a dialectical problem.

Engels sought a chart through human history and the social struggle in the writings of Marx on ethnology. He took part of them, but not the whole, for his guide, making even unfinished remarks by Marx into his canon, encouraging others to do so. He introduced his own critique, and contributed to the science of man in a concrete way in so doing. His role is ambivalent, partly canonical, partly scientific, in relation to Marx.

Marx began his publication during the early 1840 s as a philosophical anthropologist, to whom the empirical study of man was a central concern, but the particular empirical studies were not. The empirical ethnographic studies, on the other hand, were not strongly developed, and could not support the empirical anthropology which is implicit in the program of the Economic-Philosophical Manuscripts. During the next four decades Marx closely studied the empirical sciences of man in the course of their development. Ethnologists such as A. Bastian,

${ }^{1}$ Ib., pp. 324ff. 
E. B. Tylor, in addition to those mentioned above, were an important part of his readings and critique in this field. Thus, as social and cultural anthropology became increasingly a concrete empirical science, Marx moved from an abstract position to that in which the scientific, materialist method was worked out, and as the scientific focus was developed in the field, participating in the movement.

\section{ADDITIONS}

\section{1: LUKÁCS'S EXPLICATION OF THE SOCIAL AND NATURAL PHILOSOPHIES OF MARX AND ENGELS}

The separation of prehistoric from historic man was posited in a dirct way by Lukács, Geschichte und Klassenbewusstsein, op. cit., pp. 230 and 408f.; he indicates at the same time that Engels made the separation more sharply than Marx had, but in the same direction; he based himself on the letter of Engels to Marx of December 8, 1882 (MEW, Vol. 35, p. 125).

Lukács was an original explorer of the works of Marx and Engels in this regard as in many others, yet he has given but a one-sided account of Marx's natural philosophy, even taking into consideration the fact that he had no access at the time of his writing to various works of Marx (The Economic-Philosophical Manuscripts, The German Ideology, the Grundrisse) published after 1923. We bear in mind only the positions worked out by Marx in Capital in this connection. Cf. Lukács, op. cit., p. 230. Here he sees a) no difference between Marx and Engels in reference to primitive man in his relation to nature, and b) the separation of primitive from civilized man by Marx. But this is a simplification that is controverted by a careful reading of Capital.

The same point is raised by Lukács, op. cit., pp. $407 \mathrm{ff}$. Here his presentation is marred by an error that is simple. First (p. 408) he wishes to apply historical materialism "auf die vorkapitalistischen Zeitalter". Then he quotes Engels's Origin of the Family in reference to the "struktiven Unterschied zwischen dem Zeitalter der Zivilisation und der ihr vorangegangenen Epochen" (ib.). Evidently I ukács here identified the pre-capitalist with the pre-civilized ages as one. But to this it must be objected that the era of capitalism and that of civilization are not coterminous. (Fourier would have argued the contrary.) Engels, in fact, never identified the historical materialist method in exclusive reference to capitalism, and was ambivalent in regard to its application to ancient society. Moreover, we perceive a complex error in Lukács, not of simple fact, but of construction: he identifies the development of the science of the economy with the growth of the capitalist economy and the era of capitalist societv. He then proposes that this is so because the economy has become independent in the capitalist era (p. 407). This line of argument is based on the identification of the science, economics, and the object of its study, economic life, production and relations, in society. But this is what was to have been proved. (The ideal or desire of the capitalists to have a state of laissez-faire is not the same as an autonomous economic life established in fact. The independence of the economic life is not the same as the desire for or the consciousness of such independence. Indeed, the consciousness comes, like Hegel's philosopher, long after the feast.)

Moreover, the economic life of the period in which the capitalist relations predominate is not identical with the period of the production and relations of 
capital which arise in society long before they are predominant, as in classical, feudal, etc., societies. (This, however, since we are reviewing the increasing degrees of the capitalist relations, cannot be taken by its negation as the basis for the identification of capitalism and civilization.) Again, if we are seeking the economic factor in history, this is not the same as historical materialism. (This has been often enough said, and by those who are Lukács's intellectual equals and inferiors.) Restricting ourselves to the economic factor alone, we find it in the period prior to the rise of civilization, that is, in primitive or ancient societies, in civilization prior to the predominance of the capitalist relations of production in society, etc. Lukács ignored, in this regard, the work of Heinrich Cunow (see above, p. 243, note 3), whom he had opposed on other grounds (Lukács, op. cit., pp. $185,190,595)$. But it is unwise to ignore your enemies. Lukács's point remains that economic science arose under capitalism, when consciousness of the economic relations in society of their action upon other social relations, attained a level of actuality never before reached. This is not the same as the constatation of the existence of those economic relations and of their action upon the other social relations.

\section{2: HUMAN AND NATURAL HISTORY IN THE GERMAN IDEOLOGY}

Engels took another view of The German Ideology in 1888, writing in the Vorbemerkung to his Ludwig Feuerbach: "I sought out and examined the old manuscript of 1845-46 once again. The part about Feuerbach is not complete. The finished part consists of a presentation of the materialist interpretation of history, which proves only how incomplete our knowledge of history at that time was." (MEW, Vol. 21, p. 264) Engels's point appears to be that Marx and he limited themselves to a "Darlegung der materialistischen Geschichtsauffassung", and this limitation proved only how incomplete etc. The alternative interpretation is that the substance of their presentation, as opposed to their having restricted themselves to this matter alone, a formal matter, proves only how incomplete their knowledge of economic history was at that time. (For the materialist interpretation of history one would have to know not only history, including economic history, but also the system of economics aside from its historical aspect, and other matters of society, social history, etc., as well.)

The scope of the economic factor is alluded to in The German Ideology, Ch. 1, Section 3, "Kommunismus, Produktion der Verkehrsform selbst" (MEW, Vol. 3, pp. 70-77). Here the collision between productive forces and Verkehr is taken up by Marx. Verkehr is intended to mean on the one hand the relations between the public, external constitution of society, its institutions, and on the other hand, the personal side of the social relations, pertaining to the individual, the subjectivity of mankind. The objective and the subjective sides are brought together: "Dagegen geht die Entwicklung in Ländern, die, wie Nordamerika [Goethe!], in einer schon entwickelten Geschichtsepoche von vorn anfangen, sehr rasch vor sich. Solche Länder haben keine andern naturwüchsigen Voraussetzungen ausser den Individuen, die sich dort ansiedeln und die hierzu durch die ihren Bediurfnissen nicht entsprechenden Verkehrsformen der alten Länder veranlasst wurden. Sie fangen also mit den fortgeschrittensten Individuen der alten Länder und daher mit der diesen Individuen entsprechenden entwickeltsten Verkehrsform an, noch ehe diese Verkehrsform in den alten Ländern sich durchsetzen kann." (p. 73) The progressive individuals, as we see, have no burden of older Verkehrsformen; hence they begin with the most highly developed Verkehrsform, as corresponding to these individuals. (This is a step back from the more advanced 
statement in the Theses on Feuerbach, in which the verb is not "entsprechen" but "sein". "Corresponding to" leaves out the more daring and exact expression of the etiology of the advancement of the individuals in its relation to the advancement of the Verkehrsform. We are, moreover, faced with the reference to Verkehrsform, as opposed to the internalization of the Verkehr, which was posited in Marx's Critique of the Hegelian Philosophy of Right and the Economic-Philosophical Manuscripts.)

(The footnote to this passage of The German Ideology mentions personal energy of individuals of the various nations, energy through race mixture. This is likewise a step back from a social theory, introducing biological elements which Marx later rejected. In passing it is to be noted that in this text the biological element is held to be active not only in the primitive but also in the civilized condition of man.)

Those who have emigrated to the New World have no natural presuppositions other than the individuals, who are freed of the Verkehrsformen that do not correspond to their wants. Man can therefore be selective; the Verkehrsformen do not form a system that must move as a whole; that which is unnecessary, irrational, uneconomical, irrelevant to one's needs, superfluous can be left behind. This is the picture of the rational man, the homo economicus, not only in respect of the economic relations of production, etc., but of energy, resources, human relations, posited by the young Marx, and which remains to be discussed.

The theory of the Verkehrsform is generalized by Marx to embrace new forms of power unencumbered by interests, etc. from earlier epochs, the colonies of ancient Carthage and Greece, medieval Iceland and Sicily. Marx brought out the subjective side of the Verkehrsform in its relation to the objective: "Die Verwandlung der persönlichen Mächte (Verhältnisse) in sachliche" in connection with the division of labor (p. 74). This position is not the resolution of the dialectical problem of the internal and external sides of man, however; the problem is composed in the chapter on the Fetishism of Commodities in Capital, Vol. 1. The issue is raised in The German Ideology in reference to the contradiction (collision) between the productive forces and the Verkehrsformen in their external side as a dialectic; in the reference in Capital, however, both sides of man are related in their interaction with the commodity exchange relation in society: there a definite relation between men assumes the fantastic relation between things. Thereby not only is the problem in the abstract, but the basis whereby its composition in society in concrete form is arrested is set forth.

The editors of Marx-Engels Werke, Vol. 3, p. ix, exemplify the meaning of Verkehrsform as "die jeweilige Gesamtform der Produktionsverhältnisse". This meaning is in one sense narrower than that indicated above for The German Ideology; in another sense it arches over that which the Verkehrsform comes into collision with, for it then would come into collision with itself. Cornu, op. cit., pp. $182 \mathrm{n}$. and $183 \mathrm{n}$., citing the French translation, L'Ideologie allemande (1968), pp. 90f., translates Verkehr as "rapports sociaux". The English translation of Verkehr is given as "intercourse" (op. cit.). Marx wrote on the meaning of Verkehr as commerce (in French), cp. Marx, letter to P. V. Annenkov, December 28, 1846 (MEW, Vol. 27, pp. 453). 